\title{
Dietary L-Valine Improved Growth, Antioxidant Capacity, and Alleviated Endoplasmic Reticulum Stress-Mediated Apoptosis in the Intestine of Juvenile Largemouth Bass Micropterus Punctulatus After Infection With Aeromonas Veronii
}

\author{
Tian-Ran Zhang \\ Sichuan Agricultural University - Chengdu Campus \\ Xue-Fei Zhang \\ Sichuan Agricultural University - Chengdu Campus \\ Ye Zhao \\ Sichuan Agricultural University - Chengdu Campus \\ Lin Feng \\ Sichuan Agricultural University - Chengdu Campus \\ Yang Liu \\ Sichuan Agricultural University - Chengdu Campus \\ Wei-Dan Jiang \\ Sichuan Agricultural University - Chengdu Campus \\ Pei Wu \\ Sichuan Agricultural University - Chengdu Campus \\ Xiao-Li Huang \\ Sichuan Agricultural University - Chengdu Campus \\ De-Fang Chen \\ Sichuan Agricultural University - Chengdu Campus \\ Wei Luo \\ Sichuan Agricultural University - Chengdu Campus \\ Xiao-Qiu Zhou \\ Sichuan Agricultural University - Chengdu Campus \\ Jun Jiang ( $\nabla$ fishnutr@foxmail.com ) \\ Sichuan Agricultural University - Chengdu Campus
}

\section{Research}

Keywords: Valine, growth, antioxidant, apoptosis, intestine, largemouth bass

Posted Date: June 16th, 2021

DOI: https://doi.org/10.21203/rs.3.rs-600296/v1 
License: (9) (1) This work is licensed under a Creative Commons Attribution 4.0 International License. Read Full License 


\section{Abstract}

Background: The intestine is the first line of defense against bacteria, toxins and antigens presents in the lumen of the instine. Aeromonas veronii is an opportunistic pathogen that has been related to mortality in fish. However, the protective mechanisms of intestinal damage caused by Aeromonas veronii are poorly defined. Thus, the objetive of this study was to evaluate the influence of dietary valine (Val) on growth, antioxidant capacity, and endoplasmic reticulum stress-mediated apoptosis in intestines of the juvenile largemouth bass Micropterus punctulatus after infection with Aeromonas veronii (A. veronii).

Methods: A total of 720 fish $(37.99 \pm 0.01 \mathrm{~g})$ were randomly allocated to six groups with three replicates each group, with different levels of $\operatorname{Val}(11.0,14.0,17.0,20.1,23.1$, and $26.1 \mathrm{~g} / \mathrm{kg}$ diet, respectively) for $77 \mathrm{~d}$, and then challenged with $A$. veronii.

Results: In the present study, we demonstrated that dietary Val: (1) increased the percent weight gain (PWG), specific growth rate (SGR), feed intake ( $\mathrm{FI})$, feed efficiency (FE), protein efficiency ratio (PER), protein production value (PPV), lipid production value (LPV), and ash production value (APV) $(P<0.05)$; (2) improved survival rate (SR) and alleviated intestinal injury; (3) reduced the levels of reactive oxygen species (ROS), malondialdehyde (MDA), and protein carbonyl (PC) $(P<0.05)$, and improved the intestinal antioxidant capacity by enhancing the mRNA levels of $\mathrm{Cu} / \mathrm{Zn}$ superoxide dismutase (SOD1), catalase (CAT), glutathione-S-transferase (GST), glutathione peroxidase $(G P x)$, glutathione reductase $(G R)$, and $\gamma$-glutamyl cysteine ligase catalytic subunit $(G C L C)(P<0.05)$; (4) increased nuclear NFE2-related factor 2 (Nrf2) mRNA and protein levels $(P<0.05)$; (5) reduced intestinal DNA fragments, and down-regulated the mRNA levels of $78 \mathrm{KD}$ glucose regulated protein (GRP78), activating transcription factor 6 (ATF6), inositol requiring enzyme-1 (IRE1), protein kinase RNA-dependent-like endoplasmic reticulum kinase $(P E R K)$, eukaryotic initiation factor $2 a(e l F 2 a)$, activating transcription factor 4 (ATF4), C/EBP homologous protein (CHOP), cysteine-aspartic protease 9 (caspase 9), and cysteine-aspartic protease 3 (caspase 3), while up-regulating that of B-cell lymphoma-2 (Bc/2) $(P<0.05)$; (6) decreased phosphorylation of PERK ( $\mathrm{p}$ PERK) and phosphorylation of elF2a (p-elF2a), caspase 9, and caspase 3 protein levels.

Conclusion: Dietary optimal Val level enhanced the growth performance and the intestinal antioxidant capacity via the Nrf2 signaling pathway after infection with A. veronii. Furthermore, this study is the first to demonstrate the role of Val in reducing ERS-mediated apoptosis through modulation of the PERK/elF2a signaling pathway. Finally, Quadratic regression analysis of the SGR indicated that the dietary Val requirement of largemouth bass (37.99$162.92 \mathrm{~g}$ ) was $21.50 \mathrm{~g} / \mathrm{kg}$ diet, corresponding to $46.64 \mathrm{~g} / \mathrm{kg}$ protein.

\section{Introduction}

Valine (Val) is required by fish [1] and is involved in multiple physiological processes including protein synthesis, lipolysis, and immunity [2-4]. Val deprivation reduces both growth and feed efficiency, as reported for Nile tilapia Oreochromis niloticus [1, 5], juvenile golden pompano Trachinotus ovatus [6], juvenile red drum Sciaenops ocellatusand [7], juvenile blunt snout bream Megalobrama amblycephala [8], juvenile red sea bream Pagrus major [9], grass carp Ctenopharyngodon Idella [3], and Jian carp Cyprinus carpio var. Jian [10]. The largemouth bass Micropterus salmoides is a commercially important carnivorous species with annual production levels in China of over $4.5 \times 10^{8} \mathrm{~kg}$ in 2019 [11]; it provides good quality flesh, is fast-growing, and has a high market value [12]. However, little is known of the dietary Val requirement in this fish. 
Good fish growth is associated with intestinal health [13]. Intestinal health is dependent on the maintenance of the intestinal structure, and is adversely affected by high levels of reactive oxygen species (ROS) [14]. The overproduction of ROS could lead to damage to the intestines in fish [15]. Fish have both enzymatic and nonenzymatic defense systems used to scavenge excessive ROS [16, 17]. Nuclear factor erythroid 2-related factor 2 (Nrf2) plays a fundamental part in redox homeostasis in fish [18]. The Nrf2 binds to the cytosolic protein chaperone Keap1 in its inactive state under normal physiological conditions $[19,20]$. However, under oxidative stress, Nrf2 detaches from Keap1 and enters the nucleus, binding to antioxidant response elements (AREs) that initiate ARE-mediated downstream gene expression [21]. Previous studies showed that dietary Val increased $\mathrm{Cu} / \mathrm{Zn}$ superoxide dismutase (SOD1), catalase (CAT), glutathione peroxidase (GPx), glutathione S-transferase (GST) and glutathione reductase (GR) activities, and glutathione (GSH) content in grass carp gill [22] and serum total antioxidant capacity and SOD activities in juvenile golden pompano [6]. Luo et al. reported dietary Val increased SOD1, CAT, and selenium-dependent glutathione peroxidase (Se-GPx) activities by regulating Nrf2 mRNA expression [3]. A study on hypercholesterolemic rats also showed that Val was a useful antioxidant and regulated SOD and GPx activities [23]. These results suggested that Val might exert a positive effect on intestinal antioxidative capacity in fish. Nevertheless, to date, there is no specific knowledge about the impact of Val on intestinal antioxidant status in fish.

The maintenance of intestinal structural integrity is dependent on cellular apoptosis [24]. The endoplasmic reticulum (ER) organelle is implicated in numerous processes including apoptosis, particularly in epithelial cells [25]. A growing body of evidence indicates that excess ROS impairs ER homeostasis and may cause ER stress (ERS) [26-29]. The protein kinase RNA-like ER kinase (PERK), expressed in the ER membrane, plays an essential role in preserving ER homeostasis through phosphorylating the a subunit of the eukaryotic initiation factor 2 (elF2). The phosphorylated elF2a promotes increased translation of ATF4, which increases recruitment of the transcription factor C/EBP homologous protein (CHOP) [30,31]. CHOP has pro-apoptotic activity and triggers apoptosis by modulating the expression of both Bcl2 and Bax [32]. Dietary Val decreases DNA fragmentation and expression of caspases 3, 8, and 9 in grass carp gills [22]. A study on leukemia cells cultured in Val-deficient medium showed increased DNA fragmentation and caspase 3 activity [33]. However, whether dietary Val can alleviate ERS-mediated apoptosis by regulating PERK/elF2a in fish requires investigation.

Here, we investigated the influence of dietary Val on growth, the antioxidant capability and ERS-medicated apoptosis in the intestine of the largemouth bass after infection with Aeromonas veronii ( $A$. veronii). In addition, the dietary Val requirement for the largemouth bass was determined.

\section{Materials And Methods}

\section{Experimental diets and design}

The details of the basal diet are shown in Table 1. The protein sources were fish and peanut meal, and gelatin. Lipids and carbohydrates were provided by soybean oil and wheat flour, respectively. L-Val supplementation provided Val levels at 11.0 (control), 14.0, 17.0, 20.1, 23.1, and $26.2 \mathrm{~g} / \mathrm{kg}$ diet, respectively. As previously described, all diets were rendered isonitrogenous by glycine supplementation [10], and the protein level was maintained at $460 \mathrm{~g} / \mathrm{kg}$ [34]. The dry ingredients were pulverized using a 60-mesh screen. The material was mixed to homogeneity with oil and water and extruded using a twin-screw extruder (MY-165) with a 4-mm die. The material was dried at room temperature and stored at $-20^{\circ} \mathrm{C}$. 


\section{Feeding trial}

All experimental procedures used were approved by the Animal Care Advisory Committee of Sichuan Agricultural University (permit NO. DKY-2018202027). The feeding trial was performed at Ya'an Experimental Station using largemouth bass from a local farm (Sichuan, China). Before the trial, the fish were acclimatized for 28 days. A total of 720 fish with a mean weight of $37.99 \pm 0.01 \mathrm{~g}$ were randomly assigned into 18 concrete tanks $(200 \times 100$ $\left.\times 105 \mathrm{~cm}^{3}\right)$, resulting in 40 fish per tank. Fish were fed their allocated diets to apparent satiation twice (8:00 a.m. and 6:30 p.m.) daily for 77 d. Forty minutes after feeding, the unconsumed feed was collected, dried, and weighed to determine intake [35]. Each tank was connected to a flowing water system. The water temperature and $\mathrm{pH}$ value were maintained at $23.3 \pm 1.7^{\circ} \mathrm{C}$ and $7.0 \pm 0.5$, respectively. The level of dissolved oxygen was above $5.0 \mathrm{mg} / \mathrm{L}$, and the $\mathrm{NH}_{4}{ }^{+}-\mathrm{N}$ and $\mathrm{NO}_{2}{ }^{-}-\mathrm{N}$ levels were below 0.50 and $0.05 \mathrm{mg} / \mathrm{L}$, respectively.

\section{Challenge treatment and sample collection}

Fish were weighed before the challenge trial. The $A$. veronii used in the challenge test was kindly supplied by the Department of Basic Veterinary, Veterinary Medicine College, Sichuan Agricultural University. Ten fish with weights from each tank were injected intraperitoneally with $0.2 \mathrm{~mL}$ of $A$. veronii $\left(1 \times 10^{7} \mathrm{~mL} / \mathrm{CFU}\right)$ suspension, as previously determined (data not shown) for $7 \mathrm{~d}$. The experimental conditions and management were identical to those in the feeding trial.

At the beginning and end of the feeding trial, fish were fasted $24 \mathrm{~h}$, weighed, and counted. Nine fish from each group at the start and three at the end of the trial were randomly collected to measure the initial and final carcass proximate composition, respectively. At the end of the challenge trial, all fish were anesthetized with $100 \mathrm{mg} / \mathrm{L}$ MS222. The intestines from three fish were fixed in phosphate-buffered $10 \%$ formalin and samples from another six fish in each tank were removed, frozen, and stored at $-80^{\circ} \mathrm{C}$ for further analysis.

\section{Histological analysis}

Histological analyses were performed as previously described [36]. Briefly, after fixing in 10\% neutral buffered formalin, the intestines were trimmed into cassettes, dehydrated in ethanol gradients, cleared with xylene, and embedded in paraffin wax. Sections $(5 \mu \mathrm{m})$ were stained with hematoxylin and eosin (H\&E) photographed under light microscopy (Axio Imager 2, Zeiss, Oberkochen, Germany). The histological damage to the intestine was evaluated by a previously established scoring standard [37].

\section{Biochemical analysis}

Crude protein (CP), crude lipid (ether extract, EE), moisture, and ash of both feed and fish body were assayed according to the AOAC standard methods [38]. Intestine were homogenized with 10 volumes (w/v) of ice-cold physiological saline, centrifuged at $6000 \mathrm{~g}$ for $20 \mathrm{~min}$ at $4^{\circ} \mathrm{C}$, and the supernatants retained for analyzing biochemical parameters. The protein concentrations were measured as previously described [39]. The ROS were assessed by the oxidation of 2'7'-dichlorodihydrofluorescein diacetate to fluorescent dichlorofluorescein [40, 41]. The MDA [42] and PC [3] contents were determined by the thiobarbituric acid reaction and 2,4-

dinitrophenylhydrazine reagent, respectively. ASA and AHR activities were determined as previously described [16]. T-SOD, CAT, GST, GPx, and GR activities were measured by commercial kits (Nanjing Jiancheng Bioengineering Institute, Nanjing, China) as described [43]. The GSH content was assayed using 5-thio-2-nitrobenzoate as previously described [36]. 


\section{DNA fragmentation}

The DNA fragmentation was evaluated by the method of Weil et al. [44]. Agarose gel electrophoresis (1\%) was used to visualize the DNA laddering [45]. Gels were photographed and examined using a Gene Genius Bio-Imaging system (Syngene, Frederick, MD, USA). The DNA fragmentation assay of each sample was performed at least three times.

\section{Real-time quantitative PCR}

Intestinal total RNA was extracted using the TRIzol reagent (TaKaRa, Dalian, China) and its integrity and purity were assessed by agarose gel electrophoresis (1\%) and UV-spectroscopic analysis (A260:280 nm ratio), respectively. Subsequently, single-stranded cDNA was transcribed using the PrimeScript RT Reagent Kit with gDNA Eraser (TaKaRa, Dalian, China). All the RT-qPCR analyses were performed using a CFX9 Real-Time PCR Detection System (Bio-Rad, Laboratories, Inc., USA). Specific primers were designed for RT-qPCR based on the GenBank sequences of largemouth bass (Table 2). Melting curves were used to verify the reaction specificities.

Amplification efficiencies of target and housekeeping genes were determined from standard curves of 10-fold serial dilutions. Results were calculated using the $2^{-\Delta \Delta C T}$ method after verifying approximately $100 \%$ amplification efficiency of the primers [46].

\section{Western blot analysis}

Western blot was performed as in our previous study [36]. Briefly, after extraction of intestine protein, the protein concentration was determined by a protein quantification kit (Beyotime, Shanghai, China). Samples containing equal amounts of protein were separated by SDS-PAGE and transferred to polyvinylidene difluoride (PVDF) membranes. Membranes were then soaked in blocking buffer for $1 \mathrm{~h}$ at room temperature, and incubated overnight at $4^{\circ} \mathrm{C}$ with the primary antibodies. Antibodies directed against Nrf2, Keap1, PERK, phospho-PERK (Thr982, p-PERK), elF2a, phospho-elF2a (Ser51, p-eIF2a), caspase 9, caspase 3, $\beta$-actin, and lamin B1 were purchased from Cell Signaling Technology (MA, USA). The blots were then washed with TBST three times for 10 min each, and then incubated for $1 \mathrm{~h}$ with the secondary antibody at room temperature and again washed with three changes of TBST. Finally, the ECL kit (Beyotime, Shanghai, China) was used to visualize signals. Protein expression was quantified using the Gel-Pro Analyzer (Media Cybernetics Bethesda, MD, USA), and the relative densities of bands measured using Image Lab software (vs 3.0).

\section{Statistical analysis}

The results were expressed as means \pm standard error (S.E.). All data had been tested on homogeneity of variance before analysis and were then subjected to one-way analysis of variance (ANOVA). Differences among the dietary Val treatments were analyzed with Duncan's multiple-range test using SPSS 25.0 for Windows. Pearson's correlation analysis was used for correlation determination. The relationships between dietary Val and growth performance, antioxidant parameters, and apoptosis parameters were subjected to a quadratic regression method. $P<0.05$ was considered statistically significant.

\section{Results}

\section{Growth performance and body deposition}


The growth performance of largemouth bass fed with graded amounts of Val is shown in Table 3. There was no significant effect on survival rate $(\mathrm{SR},>98 \%)$ among the dietary Val treatments. The final body weight (FBW), percent weight gain (PWG), and specific growth rate (SGR) increased gradually in proportion to with increasing dietary Val, plateauing at 20.1 to $23.1 \mathrm{~g} / \mathrm{kg}$ diet and deceasing thereafter $(P<0.05)$. The feed intake $(\mathrm{FI})$ and feed efficiency (FE) increased significantly with increasing Val up to $23.1 \mathrm{~g} / \mathrm{kg}$ diet and then decreased $(P<0.05)$. The protein efficiency ratio (PER) increased in relation to Val levels up to $20.1 \mathrm{~g} / \mathrm{kg}$ diet and then plateaued $(P>0.05)$. The protein production value (PPV) and lipid production value (LPV) rose gradually up to $20.1 \mathrm{~g}$ Val/ $\mathrm{kg}$ diet and then decreased $(P<0.05)$. Fish receiving 20.1 and $23.1 \mathrm{~g} \mathrm{Val} / \mathrm{kg}$ diet had a significantly improved ash production value (APV) $(P<0.05)$. Quadratic regression analysis of SGR estimated the dietary Val requirement of the largemouth bass to be $21.50 \mathrm{~g} \mathrm{Val} / \mathrm{kg}$ diet, corresponding to $46.64 \mathrm{~g} / \mathrm{kg}$ of dietary protein (Fig. 1).

\section{Intestinal histopathology}

After infection with $A$. veronii, the SR of fish receiving graded amounts of Val is presented in Fig. 2 . The SR in fish with $20.1 \mathrm{~g} \mathrm{Val} / \mathrm{kg}$ diet was higher than in fish receiving other dietary treatments after $A$. veronii infection. The histopathological analysis of the intestines is showed in Fig. 3. Edematous mucosa (black arrow) and villous necrosis (red thick arrows) were observed in the intestines for fish fed 11.0, 14.0, 17.0, $26.2 \mathrm{~g} \mathrm{Val} / \mathrm{kg}$ diet after $A$. veronii infection. Histological scores of intestines are shown in Table 4. Fish fed 11.0, 14.0, 17.0, and $26.2 \mathrm{~g}$ $\mathrm{Val} / \mathrm{kg}$ diet had higher intestinal histopathological scores than these fish fed 20.1 and $23.1 \mathrm{~g}$ Val/ $\mathrm{kg} \operatorname{diet}(P<$ 0.05).

\section{Intestinal antioxidant capacity}

The amounts of ROS, MDA, and PC in fish intestines declined with increasing dietary Val levels up to $20.1 \mathrm{~g} / \mathrm{kg}$ diet, increasing thereafter $(P<0.05$, Table 5). In contrast, activities of AHR, CAT, GPx, and GR rose up to 20.1, 23.1, 23.1 , and $20.1 \mathrm{~g} \mathrm{Val} / \mathrm{kg}$ diet, respectively, diminishing thereafter $(P<0.05)$. The ASA and GST activities also rose up to 17.0 and $20.1 \mathrm{~g} \mathrm{Val} / \mathrm{kg}$ diet, respectively, after which they were maintained $(P>0.05)$. The T-SOD activity was enhanced in response to Val, reaching a plateau between 14.0 to $23.1 \mathrm{~g} / \mathrm{kg}$ diet, and then decreased $(P<0.05)$. The fish receiving 17.0 and $20.1 \mathrm{~g} \mathrm{Val} / \mathrm{kg}$ diet had higher $\mathrm{GSH}$ content $(P<0.05)$.

The effects of dietary Val on antioxidant-related gene expression in the intestine of largemouth bass after infection with $A$. veronii are shown in Fig. 4 and Fig. 5. Fish that received the 20.1, $23.1 \mathrm{~g} \mathrm{Val} / \mathrm{kg}$ diet had higher SOD1 mRNA levels $(P<0.05)$. The CAT, GR, GCLC, and Nrf2 mRNA levels increased gradually in response to increasing Val up to $23.1 \mathrm{~g} / \mathrm{kg}$ diet and descended thereafter $(P<0.05)$. Similarly, the GST mRNA levels were significantly up-regulated up to $20.1 \mathrm{~g} / \mathrm{kg}$ diet, and then descended $(P<0.05)$. Dietary supplementation with Val significantly increased GPx mRNA levels, which then plateaued between 17.0 and $26.2 \mathrm{~g}$ Val $/ \mathrm{kg}$ diet. The Keap1 mRNA levels diminished gradually up to $17.0 \mathrm{~g} \mathrm{Val} / \mathrm{kg}$ diet and increased thereafter $(P<0.05)$. The effects of dietary Val on protein levels of Nrf2 and Keap1 in the intestine are shown in Fig. 6. The cytosolic Nrf2 and nuclear Nrf2 protein levels were significantly enhanced in fish fed $20.1 \mathrm{~g} \mathrm{Val} / \mathrm{kg}$ diet $(P<0.05)$.

\section{ERS-medicated apoptosis signaling pathway in the intestine}

The effects of Val on DNA fragmentation in fish intestines are shown in Fig. 7. Dietary Val counteracted the DNA fragmentation, seen as a ladder-like pattern, caused by $A$. veronii infection. The transcriptional levels of ERSmedicated apoptotic signaling molecules are presented in Fig. 8 and Fig. 9. The GRP78 mRNA level diminished in response to Val up to $17.0 \mathrm{~g} / \mathrm{kg}$ diet $(P<0.05)$ and plateaued thereafter $(P>0.05)$. The ATF6 mRNA levels decreased gradually up to $20.1 \mathrm{~g} \mathrm{Val} / \mathrm{kg}$ diet $(P<0.05)$, maintaining this level between 23.1 and $26.2 \mathrm{~g} / \mathrm{kg}$ diet $(P>$ 
0.05). The mRNA levels of IRE1, ATF4, and CHOP diminished in response to increasing Val concentration up to $20.1 \mathrm{~g} / \mathrm{kg}$ diet but increased thereafter $(P<0.05)$. Similarly, the $P E R K$ and elF2a mRNA levels were reduced up to $17.0 \mathrm{~g} \mathrm{Val} / \mathrm{kg}$ diet, after which they all rose $(P<0.05)$. In contrast, the $B c / 2 \mathrm{mRNA}$ levels rose in response to increased Val up to $20.1 \mathrm{~g} \mathrm{Val} / \mathrm{kg}$ diet, and then diminished $(P<0.05)$. No significant differences were observed in Bax mRNA levels among the treatments $(P>0.05)$. Fish receiving $20.1 \mathrm{~g} \mathrm{Val} / \mathrm{kg}$ diet had the lowest caspase 9 mRNA levels compared to the fish that received other concentrations of Val $(P<0.05)$. The caspase 3 mRNA levels were reduced in response to Val up to $17.0 \mathrm{~g} \mathrm{Val} / \mathrm{kg}$ diet, rising thereafter $(P<0.05)$.

The effects of dietary Val on the PERK, elF2a, caspase 9, and caspase 3 protein contents of the intestines are shown in Fig. 10. Both p-PERK and p-elF2a levels were significantly reduced in fish fed 20.1 and $26.2 \mathrm{~g} \mathrm{Val} / \mathrm{kg} \mathrm{diet,}$ respectively $(P<0.05)$. Fish that received $20.1 \mathrm{~g} \mathrm{Val} / \mathrm{kg}$ diet had significantly lower caspase 9 and caspase 3 protein levels than the fish fed 11.0 and $26.2 \mathrm{~g} \mathrm{Val} / \mathrm{kg}$ diet, respectively $(P<0.05)$.

\section{Discussion}

\section{Dietary Val enhanced fish growth}

We have, firstly, verified the importance of the essential amino acid Val for the largemouth bass. Diets supplemented with Val augmented the FBW, PWG, and SGR, suggesting that dietary Val stimulated the growth of largemouth bass. Similar observations have been reported in Nile tilapia [5], red drum [7], and golden pompano [6]. The quadratic regression analysis for SGR showed that the dietary Val requirement of the largemouth bass (37.99$162.92 \mathrm{~g}$ ) was $21.50 \mathrm{~g} \mathrm{Val} / \mathrm{kg}$ of the diet, the equivalent of $46.64 \mathrm{~g} / \mathrm{kg}$ of dietary protein. This is higher than that reported in Nile tilapia $(35.39 \mathrm{~g} / \mathrm{kg})$ [5] and red drum $(33.60 \mathrm{~g} / \mathrm{kg})$ [7] but comparable to that reported for the golden pompano $(46.22-46.91 \mathrm{~g} / \mathrm{kg}$ ) [6]. These disparities could be ascribed to differences in fish size and age, growth environment, and growth stages. In addition, the SGR was positively associated with $\mathrm{FI}(r=0.937, P=$ $0.006)$ and FE $(r=0.973, P=0.001)$ (Table 6) and FE was positively related to PER $(r=0.914, P=0.011), P P V(r=$ $0.945, P=0.004)$, LPV $(r=0.904, P=0.013)$, and APV $(r=0.996, P=0.000)$ (Table 6). These results suggested that the effects of Val on growth may be due to increased FI and FE and the improved FE was partly due to increased nutrient retention.

Dietary Val improved intestinal antioxidant capacity via Nrf2 signaling pathway after infection with A. veronii

A. veronii is an opportunistic pathogen that has been related to mortality in a number of species (mostly fish) [47]. The SR after challenge reflects the fish disease resistance [48]. Here, dietary Val significantly improved the SR after infection with $A$. veronii, which suggested that dietary Val might improve disease resistance. The intestine is one of the target organs of $A$. veronii, which causes damage to the intestinal anatomy [49]. In this study, dietary Val alleviated intestinal injury after infection with $A$. veronii. The oxidative condition of intestinal epithelial cells is linked to their structural integrity. Although ROS are normally produced during intracellular physiological reactions, excess production accompanied by insufficient elimination results in protein oxidation and lipid peroxidation that cause structural damage to the cells and, in turn, to the intestinal epithelium. Previous studies showed that $A$. veronii infection led to ROS overproduction [15,49-51]. The degree of protein oxidation and lipid peroxidation can be reflected by the PC and MDA concentrations, respectively [52]. Here, we found that dietary Val significantly reduced ROS, PC, and MDA levels after infection with $A$. veronii. Similar findings were seen in the gill and muscle of the grass carp $[3,22]$. ROS was found to be positively associated with the MDA content $(r=0.976, P=0.001)$ and PC content $(r=0.949, P=0.004)$. These results indicated that dietary Val might alleviate lipid peroxidation and 
protein oxidation damage by decreasing ROS accumulation. The most damaging ROS are superoxide and hydroxyl radicals [53]. The ASA and AHR activities are used as a measure of the ability of the cell or tissue to scavenge superoxide and hydroxyl radicals, respectively [54]. We found that optimal levels of dietary Val increased the activities of both ASA and AHR which correlated negatively with the ROS levels (ASA $r=-0.935, P=0.006$ and AHR $r=-0.935, P=0.006$ ) suggesting that dietary Val suppressed ROS accumulation by improving the total capacities of scavenging superoxide and hydroxyl radicals. This result is consistent with reports on the gills of grass carp and serum of the golden pompano [6,22]. The ROS removal also largely relies on the antioxidant system, including non-enzymatic antioxidants (GSH) and antioxidant enzymes (SOD, CAT, GST, GPx, and GR) [17, 55]. In this study, dietary appropriate Val increased the content of GSH and the activities of SOD, CAT, GST, GPX, GR in the intestine. The ROS concentration was negatively related to SOD $(r=-0.901, P=0.014)$, CAT $(r=-0.805$, $P=0.053)$, and GST $(r=-0.892, P=0.017)$ activities, suggesting that dietary Val promoted ROS scavenging partly through the modulation of antioxidant enzymes. This finding is consistent with results on the grass carp, Nile tilapia, and golden pompano, which reported that dietary Val increased the activities of antioxidant enzymes in the gills and muscles of grass carp, liver of the Nile tilapia, and serum of the golden pompano [1, 3, 6, 22].

The activities of enzymes are closely associated with their mRNA levels [56]. Here, we found that optimal levels of dietary Val significantly elevated the mRNA levels of SOD1, CAT, GST, GPX, and GR. Furthermore, the mRNA levels of SOD1 ( $\mathrm{r}=0.861, P=0.028), C A T(\mathrm{r}=0.966, P=0.002)$, and $G P X(\mathrm{r}=0.840, P=0.036)$ were positively correlated with the activities of their respective enzymes. Glutamate cysteine ligase is an enzyme responsible for the synthesis of GSH, a process that is dependent on the GCLC catalytic subunit [20]. We observed that dietary Val significantly enhanced the mRNA levels of GCLC. Nrf2 regulates the transcription of various antioxidant enzymes in the nucleus, a process that can be inhibited by Nrf2 binding to the cytoplasmic Keap1, preventing translocation to the nucleus $[19,20]$. The activation of the Nrf2 signaling pathway was positively linked to the nuclear Nrf2 protein level, which could be enhanced either by increasing the transcription of Nrf2 or by decreasing the level of Keap $1[57,58]$. Here, we found that appropriate levels of dietary Val significantly augmented both the Nrf2 mRNA and the level of the protein product in the nucleus while decreasing Keap1 mRNA. Furthermore, the Nrf2 mRNA level was positively associated with the mRNA levels of CAT $(r=0.962, P=0.002), \mathrm{GR}(r=0.810, P=0.051)$, and $\operatorname{GCLC}(r=0.925, P=0.008)$. These results demonstrated that dietary Val improved intestinal antioxidant capacity by up-regulated the antioxidant enzyme-related genes transcription via the Nrf2 signaling pathway.

Dietary Val ameliorated ERS-mediated apoptosis through modulation of the PERK/elF2a signaling pathway in intestines after infection with A. veronii

Apoptosis may result from ROS-induced oxidative damage which, if excessive, may seriously damage the structural integrity of the intestine [24]. Apoptosis is characterized by DNA fragmentation [59]. Here, we found that dietary Val reduced the ladder-like pattern of DNA fragments after infection with $A$. veronii. This is consistent with results on grass carp gills and chicken sperm $[22,60]$. These results demonstrated that Val is able to protect against $A$. veronir-induced apoptosis in the intestine.

The ER is a vital subcellular organelle that regulates protein synthesis, ensures the correct folding of polypeptide chains into proteins, and maintains intracellular calcium homeostasis [61]. It has been observed that bacterial infection can impair ER homeostasis and eventually lead to ERS in fish [26-29]. The ERS is mediated by three major pathways: the PERK/elF2a pathway, the IRE1a/XBP1 pathway, and the ATF6 pathway. PERK is responsible for phosphorylating the translation initiation factor elF2 $a$ at the Ser51 site, resulting in the translation of ATF4 by the phosphorylated elF2a $[30,31]$. CHOP, a key downstream target of ATF4, can trigger apoptosis during ERS [30, 
31]. Here, we found that dietary Val significantly reduced the mRNA levels of GRP78, ATF6, IRE1, PERK, elF2a, ATF4, and $C H O P$, as well as the protein levels of p-PERK and p-elF2a, caspase 9 , and caspase 3 . These results indicated that Val ameliorated $A$. veronii-induced apoptosis through modulation of the PERK/elF2a signaling pathway. Feng et al. also reported that dietary Val significantly decreased caspase 9 mRNA in the grass carp gill [22]. To the best of our knowledge, the present study is the first report showing that dietary Val protects the intestine against infection-induced apoptosis through inhibiting the PERK/elF2a signaling pathway. We also found that ROS levels were positively correlated with the mRNAs of GRP78 $(r=0.794, P=0.059)$, ATF6 $(r=0.883$, $P=0.020), C H O P(r=0.864, P=0.026)$, and caspase $3(r=0.853, P=0.031)$, which suggested that dietary Val ameliorated ERS- mediated apoptosis by reducing the expression of related genes expression, which was partly due to decreased ROS accumulation. The decreased ROS levels induced by Val may be a consequence of the contribution of Val to GIn synthesis. Val is a substrate for GIn synthesis [62]. A previous study showed that GIn significantly decreased ROS levels in fish [63]. However, the mechanisms responsible for these effects require further investigation.

\section{Conclusion}

In conclusion, optimal concentrations of dietary Val enhanced the growth performance of the largemouth bass. In addition, dietary Val improved the intestinal antioxidant capacity via the Nrf2 signaling pathway after infection with $A$. veronii. Furthermore, this study is the first to demonstrate the role of Val in reducing ERS-mediated apoptosis through modulation of the PERK/elF2a signaling pathway in infected fish intestines. Lastly, quadratic regression analysis of SGR estimated the dietary Val requirement of the largemouth bass to be $21.50 \mathrm{~g} \mathrm{Val} / \mathrm{kg}$ diet, corresponding to $46.64 \mathrm{~g} / \mathrm{kg}$ protein.

\section{Declarations}

\section{Acknowledgements}

The authors would like to express their sincere thanks to the personnel of these teams for their kind assistance.

\section{Author contribution}

Tian-Ran Zhang, Xue-Fei Zhang, and Ye Zhao: Formal analysis, Investigation, Writing-original draft, Writing-review \& editing. Lin Feng, Yang Liu, and Wei-Dan Jiang: Formal analysis, Investigation. Pei Wu, Xiao-Li Huang, and DeFang Chen: Methodology, Resources. Wei Luo: Resources. Xiao-Qiu Zhou and Jun Jiang: Conceptualization, Formal analysis, Investigation, Writing-review \& editing.

\section{Funding}

This study was financially supported by National Key R\&D Program of China (2019YFD0900200) and the National Natural Science Foundation of China (31702362). All authors read and approved the final manuscript.

\section{Availability of data and materials}

The datasets produced and/or analyzed during the current study are available from the corresponding author on reasonable request. 


\section{Ethics approval and consent to participate}

Not applicable

\section{Consent for publication}

Not applicable.

\section{Competing Interest}

The authors declare that they have no known competing financial interests or personal relationships that could have appeared to influence the work reported in this paper.

\section{Author details}

${ }^{1}$ College of Animal Science and Technology, Sichuan Agricultural University, Chengdu 611130, China.

2 Institute of Animal Nutrition, Sichuan Agricultural University, Chengdu 611130, China.

${ }^{3}$ Key Laboratory for Animal Disease-Resistance Nutrition of China Ministry of Education, Sichuan Agricultural University, Chengdu, Sichuan 611130, P. R. China.

\section{References}

1. Xiao W, Li DY, Zhu JL, Zou ZY, Yue YR, Yang H. Dietary valine requirement of juvenile Nile tilapia, Oreochromis niloticus. Aquacult Nutr. 2017;24(1):315-23.

2. Du Y, Meng Q, Zhang Q, Guo F. Isoleucine or valine deprivation stimulates fat loss via increasing energy expenditure and regulating lipid metabolism in wat. Amino Acids. 2012;43(2):725-34.

3. Luo J, Feng L, Jiang W, Yang L, Pei W, Jun J, et al. Physical and flavor characteristics, fatty acid profile, antioxidant status and Nrf2-dependent antioxidant enzyme gene expression changes in young grass carp (Ctenopharyngodon idella) fillets fed dietary valine. Plos One. 2017;12(1):e0169270.

4. Zhang S, Zeng X, Ren M, Mao X, Qiao S. Novel metabolic and physiological functions of branched chain amino acids: a review. J Anim Sci Biotech. 2017;8:10.

5. Rodrigues RB, Hassemer MZ, Melo IWA, Neu DH, Bittencourt F, Boscolo WR. Valine in diets for juvenile Nile tilapia (Oreochromis niloticus): growth performance, chemical composition, blood parameters and skeletal muscle development. Span J Agric Res. 2019;17(2):e602.

6. Huang Z, Tan XH, Zhou CP, Yang YK, Qi CL, Zhao SY, et al. Effect of dietary valine levels on the growth performance, feed utilization and immune function of juvenile golden pompano, Trachinotus ovatus. Aquacult Nutr. 2017;24(1):74-82.

7. Castillo S, Gatlin DM. Dietary requirements for leucine, isoleucine and valine (branched-chain amino acids) by juvenile red drum Sciaenops ocellatus. Aquacult Nutr. 2017;24(3):1056-65.

8. Ren MC, Habte-Tsion HM, Liu B, Zhou QL, Xie J, Ge XP, et al. Dietary valine requirement of juvenile blunt snout bream (Megalobrama amblycephala Yih, 1955). J Appl Ichthyol. 2015;31(6):1086-92.

9. Rahimnejad S, Lee K. Dietary valine requirement of juvenile red sea bream Pagrus major. Aquaculture. 2013;416-417(5):212-8. 
10. Dong M, Feng L, Kuang SY, Liu Y, Jiang J, Hu K, et al. Growth, body composition, intestinal enzyme activities and microflora of juvenile Jian carp (Cyprinus carpio var. Jian) fed graded levels of dietary valine. Aquacult Nutr. 2012;19(1):1-14.

11. Sun J, Zhao L, Liao L, Tang X, Cui C, Liu Q, et al. Interactive effect of thermal and hypoxia on largemouth bass (Micropterus salmoides) gill and liver: aggravation of oxidative stress, inhibition of immunity and promotion of cell apoptosis. Fish Shellfish Immunol. 2020;98:923-36.

12. Li S, Ding G, Song F, Sang C, Wang A, Chen N. Comparison of dehulled, fermented and enzyme-treated soybean meal in diets for largemouth bass, Micropterus salmoides: effects on growth performance, feed utilization, immune response and intestinal morphology. Anim Feed Sci Technol. 2020;267:114548.

13. Yuan Z, Feng L, Jiang W, Wu P, Liu Y, Kuang S, et al. Dietary choline deficiency aggravated the intestinal apoptosis in association with the MAPK signalling pathways of juvenile grass carp (Ctenopharyngodon idella). Aquaculture. 2021;532(15):736046.

14. Lu Z, Feng L, Jiang W, Wu P, Liu Y, Kuang S, et al. Mannan oligosaccharides improved growth performance and antioxidant capacity in the intestine of on-growing grass carp (Ctenopharyngodon idella). Aquacult Rep. 2020;17:100313.

15. Song C, Liu B, Xu P, Xie J, Ge X, Zhou Q, et al. Oxidized fish oil injury stress in megalobrama amblycephala: evaluated by growth, intestinal physiology, and transcriptome-based PI3K-AKT/NF-KB/TCR inflammatory signaling. Fish Shellfish Immunol. 2018;81:446-55.

16. Jiang J, Yin L, Li J, Li Q, Shi D, Feng L, et al. Glutamate attenuates lipopolysaccharide-induced oxidative damage and mRNA expression changes of tight junction and defensin proteins, inflammatory and apoptosis response signaling molecules in the intestine of fish. Fish Shellfish Immunol. 2017;70:473-84.

17. Liu X, Feng L, Jiang W, Wu P, Jiang J, Yang D, et al. (2-carboxyethyl)dimethylsulfonium bromide (Br-DMPT) improves muscle flesh quality and antioxidant status of on-growing grass carp (Ctenopharyngodon idella) fed non-fish meal diets. Aquaculture. 2020;521:735065.

18. Giuliani ME, Regoli F. Identification of the Nrf2-Keap1 pathway in the European eel Anguilla anguilla: role for a transcriptional regulation of antioxidant genes in aquatic organisms. Aquat Toxicol. 2014;150:117-23.

19. Dong Y, Feng L, Jiang W, Liu Y, Wu P, Jiang J, et al. Dietary threonine deficiency depressed the disease resistance, immune and physical barriers in the gills of juvenile grass carp (Ctenopharyngodon idella) under infection of Flavobacterium columnare. Fish Shellfish Immunol. 2018;72:161-73.

20. Chen Y, Shertzer HG, Schneider SN, Nebert DW, Dalton TP. Glutamate cysteine ligase catalysis dependence on atp and modifier subunit for regulation of tissue glutathione levels. J Biol Chem. 2005;280(40):33766-74.

21. Raghunath A, Nagarajan R, Sundarraj K, Panneerselvam L, Perumal E. Genome-wide identification and analysis of Nrf2 binding sites-antioxidant response elements in zebrafish. Toxicol Appl Pharmacol. 2018;360:236-48.

22. Feng L, Luo J, Jiang W, Liu Y, Wu P, Jiang J, et al. Changes in barrier health status of the gill for grass carp (Ctenopharyngodon idella) during valine deficiency: regulation of tight junction protein transcript, antioxidant status and apoptosis-related gene expression. Fish Shellfish Immunol. 2015;45(2):239-49.

23. Cojocaru E, Filip N, Ungureanu C, Filip C, Danciu M. Effects of valine and leucine on some antioxidant enzymes in hypercholesterolemic rats. Health. 2014;6(17):2313-21.

24. Bakke-McKellep AM, Penn MH, Salas PM, Refstie S, Sperstad S, Landsverk T, et al. Effects of dietary soyabean meal, inulin and oxytetracycline on intestinal microbiota and epithelial cell stress, apoptosis and 
proliferation in the teleost Atlantic salmon (Salmo salar L.). Brit J Nutr. 2007;97(4):699-713.

25. Cao SS, Kaufman RJ. Endoplasmic reticulum stress and oxidative stress in cell fate decision and human disease. Antioxid Redox Sign. 2014;21(3):396-413.

26. Banerjee C, Singh A, Das TK, Raman R, Shrivastava A, Mazumder S. Ameliorating ER-stress attenuates Aeromonas hydrophila-induced mitochondrial dysfunctioning and caspase mediated HKM apoptosis in Clarias batrachus. Sci Rep. 2014;4(1).

27. Akazawa Y, Isomoto H, Matsushima K, Kanda T, Minami H, Yamaghchi N, et al. Endoplasmic reticulum stress contributes to helicobacter pylori vaca-induced apoptosis. Plos One. 2013;8(12):e82322.

28. Baird M, Woon Ang P, Clark I, Bishop D, Oshima M, Cook MC, et al. The unfolded protein response is activated in helicobacter-induced gastric carcinogenesis in a non-cell autonomous manner. Lab Invest. 2013;93(1):112-22.

29. Seimon TA, Kim M, Blumenthal A, Koo J, Ehrt S, Wainwright H, et al. Induction of ER stress in macrophages of Tuberculosis granulomas. Plos one. 2010;5(9):e12772.

30. Hu K, Zhen Q, Gong J, Cheng T, Qi L, Shao Y, et al. Palladium-catalyzed three-component tandem process: one-pot assembly of quinazolines. Org Lett. 2018;20(10):3083-7.

31. Wang W, Liu T, Liu Y, Yu L, Yan X, Weng W, et al. Astaxanthin attenuates alcoholic cardiomyopathy via inhibition of endoplasmic reticulum stress-mediated cardiac apoptosis. Toxicol appl pharmacol. 2021;412:115378.

32. Tabas I, Ron D. Integrating the mechanisms of apoptosis induced by endoplasmic reticulum stress. Nat cell Biol. 2011;13(3):184-90.

33. Ohtawa K, Ueno T, Mitsui K, Kodera Y, Hiroto M, Matsushima A, et al. Apoptosis of leukemia cells induced by valine-deficient medium. Leukemia. 1998;12(10):1651-2.

34. Li X, Zheng S, Ma X, Cheng K, Wu G. Effects of dietary protein and lipid levels on the growth performance, feed utilization, and liver histology of largemouth bass (Micropterus salmoides). Amino Acids. 2020;52(67):1043-61.

35. Jiang J, Wu X, Zhou X, Feng L, Liu Y, Jiang W, et al. Effects of dietary curcumin supplementation on growth performance, intestinal digestive enzyme activities and antioxidant capacity of crucian carp Carassius auratus. Aquaculture. 2016;463:174-80.

36. Zhao Y, Yan M, Jiang Q, Yin L, Zhou X, Feng L, et al. Isoleucine improved growth performance, and intestinal immunological and physical barrier function of hybrid catfish Pelteobagrus vachelli $\times$ Leiocassis longirostris. Fish Shellfish Immunol. 2021;109:20-33.

37. Dieleman P, Akol, Bloemena PENA, Meuwissen, et al. Chronic experimental colitis induced by dextran sulphate sodium (DSS) is characterized by TH1 and TH2 cytokines. Clin Exp immunol. 1998;114(3):385-91.

38. Horwitz W, Latimer GW. Official methods of analysis of AOAC international. AOAC International; 2005.

39. Bradford MM. A rapid and sensitive method for the quantitation of microgram quantities of protein utilizing the principle of protein-dye binding. Anal Biochem. 1976;72(1):248-54.

40. Zhang Y, Jiang W, Duan X, Feng L, Wu P, Liu Y, et al. Soybean glycinin caused NADPH-oxidase-regulated ROS overproduction and decreased ros elimination capacity in the mid and distal intestine of juvenile grass carp (Ctenopharyngodon idella). Aquaculture. 2020;516:734651. 
41. Rhee J, Yu IT, Kim B, Jeong C, Lee K, Kim M, et al. Copper induces apoptotic cell death through reactive oxygen species-triggered oxidative stress in the intertidal copepod Tigriopus japonicus. Aquat Toxicol. 2013;132-133:182-9.

42. Figueroa E, Farias JG, Lee-Estevez M, Valdebenito I, Risopatrón J, Magnotti C, et al. Sperm cryopreservation with supplementation of a-tocopherol and ascorbic acid in freezing media increase sperm function and fertility rate in Atlantic salmon (Salmo salar). Aquaculture. 2018;493:1-8.

43. Zhao Y, Zhang T, Li Q, Feng L, Liu Y, Jiang W, et al. Effect of dietary L-glutamate levels on growth, digestive and absorptive capability, and intestinal physical barrier function in Jian carp (Cyprinus carpio var. Jian). Anim Nutr. 2020;6(2):198-209.

44. Weil M, Jacobson MD, Raff MC. Are caspases involved in the death of cells with a transcriptionally inactive nucleus? Sperm and chicken erythrocytes. J Cell Sci. 1998;111(Pt 18):2707-15.

45. Wu P, Tian L, Zhou X, Jiang W, Liu Y, Jiang J, et al. Sodium butyrate enhanced physical barrier function referring to Nrf2, JNK and MLCK signaling pathways in the intestine of young grass carp (Ctenopharyngodon idella). Fish Shellfish Immunol. 2018;73:121-32.

46. Yin L, Zhao Y, Zhou X, Yang C, Feng L, Liu Y, et al. Effect of dietary isoleucine on skin mucus barrier and epithelial physical barrier functions of hybrid bagrid catfish Pelteobagrus vachelli $\times$ Leiocassis longirostris. Fish Physiol Biochem. 2020;46(5):1759-74.

47. Pei C, Song H, Zhu L, Qiao D, Yan Y, Li L, et al. Identification of Aeromonas veronii isolated from largemouth bass Micropterus salmoides and histopathological analysis. Aquaculture. 2021;540:736707.

48. Zhao J, Liu Y, Jiang J, Wu P, Jiang W, Li S, et al. Effects of dietary isoleucine on the immune response, antioxidant status and gene expression in the head kidney of juvenile Jian carp (Cyprinus carpio var. Jian). Fish Shellfish Immunol. 2013;35(2):572-80.

49. Xia L, Han P, Cheng X, Li Y, Zheng C, Yuan H, et al. Aeromonas veronii caused disease and pathological changes in Asian swamp Eelmonopterus albus. Aquacult Res. 2019;50(10):2978-85.

50. Krzymińska S, Tańska A, Kaznowski A. Aeromonas spp. induce apoptosis of epithelial cells through an oxidant-dependent activation of the mitochondrial pathway. J Med Microb. 2011;60(7):889-98.

51. Xie S, Jiang L, Wang M, Sun W, Yu S, Turner JR, et al. Cadmium ingestion exacerbates salmonella infection, with a loss of goblet cells through activation of notch signaling pathways by ros in the intestine. J Hazard Mater. 2020;391:122262.

52. Feng L, Li W, Liu Y, Jiang W, Kuang S, Wu P, et al. Protective role of phenylalanine on the ROS-induced oxidative damage, apoptosis and tight junction damage via Nrf2, tor and NF-KB signalling molecules in the gill of fish. Fish Shellfish Immunol. 2017;60:185-96.

53. Halliwell B. Free radicals and antioxidants-quo vadis? Trends Pharmacol Sci. 2011;32(3):125-30.

54. Feng L, Gan L, Jiang W, Wu P, Liu Y, Jiang J, et al. Gill structural integrity changes in fish deficient or excessive in dietary isoleucine: towards the modulation of tight junction protein, inflammation, apoptosis and antioxidant defense via NF-KB, TOR and Nrf2 signaling pathways. Fish Shellfish Immunol. 2017;63:127-38.

55. Jiang W, Tang R, Liu Y, Wu P, Kuang S, Jiang J, et al. Impairment of gill structural integrity by manganese deficiency or excess related to induction of oxidative damage, apoptosis and dysfunction of the physical barrier as regulated by NF-KB, caspase and Nrf2 signaling in fish. Fish Shellfish Immunol. 2017;70:280-92.

56. Jiang W, Hu K, Liu Y, Jiang J, Wu P, Zhao J, et al. Dietary myo-inositol modulates immunity through antioxidant activity and the Nrf2 and E2F4/cyclin signalling factors in the head kidney and spleen following 
infection of juvenile fish with Aeromonas hydrophila. Fish Shellfish Immunol. 2016;49:374-86.

57. Giudice A, Arra C, Turco MC. Review of molecular mechanisms involved in the activation of the Nrf2-ARE signaling pathway by chemopreventive agents. 2010; 647: 37-74.

58. Liu Q, Hu Y, Cao Y, Song G, Liu Z, Liu X. Chicoric acid ameliorates lipopolysaccharide-induced oxidative stress via promoting the Keap1/Nrf2 transcriptional signaling pathway in BV-2 microglial cells and mouse brain. J Agricult Food Chem. 2017;65(2):338-47.

59. Chai J, Xiong Q, Zhang P, Zheng R, Peng J, Jiang S. Induction of $\mathrm{Ca}^{2+}$ signal mediated apoptosis and alteration of IP3R1 and SERCA1 expression levels by stress hormone in differentiating C2C12 myoblasts. Gen Comp Endocrinol. 2010;166(2):241-9.

60. Bernal B, Iglesias-Cabeza N, Sánchez-Rivera U, Toledano-Díaz A, Castaño C, Pérez-Cerezales S, et al. Effect of supplementation of valine to chicken extender on sperm cryoresistance and post-thaw fertilization capacity. Poultry Sci. 2020;99(12):7133-41.

61. Cao SS, Kaufman RJ. Endoplasmic reticulum stress and oxidative stress in cell fate decision and human disease. Antioxid Redox Sign. 2014;21(3):396-413.

62. Chen L, Li P, Wang J, Li X, Gao H, Yin Y, et al. Catabolism of nutritionally essential amino acids in developing porcine enterocytes. Amino Acids. 2009;37(1):143-52.

63. Li H, Feng L, Jiang W, Liu Y, Jiang J, Li S, et al. Oxidative stress parameters and anti-apoptotic response to hydroxyl radicals in fish erythrocytes: protective effects of glutamine, alanine, citrulline and proline. Aquat Toxicol. 2013;126:169-79.

\section{Tables}

Table 1 Composition and nutrients content of basal diet 


\begin{tabular}{|c|c|c|c|}
\hline Ingredients ${ }^{1}$ & $\mathrm{~g} / \mathrm{kg}$ & Nutrients content ${ }^{6}$ & $\mathrm{~g} / \mathrm{kg}$ \\
\hline Fish meal & 90 & Crude protein & 461 \\
\hline Peanut meal & 300 & Crude lipid & 130 \\
\hline Gelatin & 180 & Ash & 96 \\
\hline Soya bean oil & 126 & Moisture & 55 \\
\hline Wheat flour & 93.5 & & \\
\hline $\mathrm{CaH}_{2} \mathrm{PO}_{4}$ & 40 & & \\
\hline Choline chloride & 10 & & \\
\hline Crystal AA premix ${ }^{2}$ & 100 & & \\
\hline Vitamin premix 3 & 10 & & \\
\hline Mineral premix 4 & 20 & & \\
\hline Valine and glycine premix ${ }^{5}$ & 15 & & \\
\hline Ethoxyquin & 0.5 & & \\
\hline Cellulose & 15 & & \\
\hline
\end{tabular}

${ }^{1}$ Fish meal (TASA Steam dried fishmeal, Peru), peanut meal (Luhua Group, China), gelatin (Henan boyang biotechnology CO., LTD, China), soya bean oil (Yihai Kerry Consumer Products Division, China), wheat flour (Hebei jinshahe group, China).

${ }^{2}$ Crystal AA premix (g/kg): histidine ( $\left.990 \mathrm{~g} / \mathrm{kg}\right), 53.16 \mathrm{~g}$; isoleucine $(990 \mathrm{~g} / \mathrm{kg}), 85.30 \mathrm{~g}$; leucine $(985 \mathrm{~g} / \mathrm{kg}), 159.55$ g; lysine ( $980 \mathrm{~g} / \mathrm{kg}), 81.27 \mathrm{~g}$; methionine $(990 \mathrm{~g} / \mathrm{kg}), 80.08 \mathrm{~g}$; cysteine $(990 \mathrm{~g} / \mathrm{kg}), 48.93 \mathrm{~g}$; phenylalanine (990 $\mathrm{g} / \mathrm{kg}$ ), $58.17 \mathrm{~g}$; tyrosine $(990 \mathrm{~g} / \mathrm{kg}), 69.30 \mathrm{~g}$; threonine $(980 \mathrm{~g} / \mathrm{kg}), 87.02 \mathrm{~g}$; tryptophan $(990 \mathrm{~g} / \mathrm{kg}), 8.76 \mathrm{~g}$. All ingredients were diluted with wheat flour to $1 \mathrm{~kg}$.

${ }^{3}$ Vitamin premix (g/kg): retinyl acetate (500 $000 \mathrm{lU} / \mathrm{g}$ ), $0.710 \mathrm{~g}$; cholecalciferol (500 $000 \mathrm{IU} / \mathrm{g}$ ), $0.072 \mathrm{~g}$; atocopherol (500 g/kg), $5.600 \mathrm{~g}$; menadione $(500 \mathrm{~g} / \mathrm{kg}), 3.312 \mathrm{~g}$; thiamine $(780 \mathrm{~g} / \mathrm{kg}), 2.568 \mathrm{~g}$; riboflavin $(800 \mathrm{~g} / \mathrm{kg})$, $0.625 \mathrm{~g}$; pyridoxine hydrochloride $(820 \mathrm{~g} / \mathrm{kg}), 1.829 \mathrm{~g}$; cyanocobalamin $(10 \mathrm{~g} / \mathrm{kg}), 2.700 \mathrm{~g}$; ascorbyl acetate (930 $\mathrm{g} / \mathrm{kg}), 16.130 \mathrm{~g}$; nicotinic acid $(990 \mathrm{~g} / \mathrm{kg}), 2.262 \mathrm{~g}$; d-calcium pantothenate $(900 \mathrm{~g} / \mathrm{kg}), 2.778 \mathrm{~g}$; folic acid (950 $\mathrm{g} / \mathrm{kg}), 0.105 \mathrm{~g}$; biotin $(20 \mathrm{~g} / \mathrm{kg}), 0.300 \mathrm{~g}$; inositol $(980 \mathrm{~g} / \mathrm{kg}), 40.816 \mathrm{~g}$. All ingredients were diluted with wheat flour to $1 \mathrm{~kg}$.

${ }^{4}$ Mineral premix (g/kg): $\mathrm{FeSO}_{4} \cdot \mathrm{H}_{2} \mathrm{O}(30.0 \% \mathrm{Fe}), 5.00 \mathrm{~g} ; \mathrm{CuSO}_{4} \cdot 5 \mathrm{H}_{2} \mathrm{O}(25.0 \% \mathrm{Cu}), 1.00 \mathrm{~g} ; \mathrm{ZnSO}_{4} \cdot \mathrm{H}_{2} \mathrm{O}(34.5 \% \mathrm{Zn})$, $5.36 \mathrm{~g} ; \mathrm{MnSO}_{4} \cdot \mathrm{H}_{2} \mathrm{O}(31.8 \% \mathrm{Mn}), 1.08 \mathrm{~g} ; \mathrm{Ca}\left(\mathrm{IO}_{3}\right)_{2}(5.0 \% \mathrm{I}), 1.10 \mathrm{~g} ; \mathrm{Na}_{2} \mathrm{SeO}_{3}(1.0 \% \mathrm{Se}), 1.25 \mathrm{~g} ; \mathrm{CoCl}_{2} \cdot 6 \mathrm{H}_{2} \mathrm{O}(12.0 \%$ Co), $0.83 \mathrm{~g} ; \mathrm{MgSO}_{4} \cdot \mathrm{H}_{2} \mathrm{O}(17.3 \% \mathrm{Mg}), 173.41 \mathrm{~g}$. All ingredients were diluted with $\mathrm{CaCO}_{3}$ to $1 \mathrm{~kg}$.

${ }^{5}$ Valine and glycine premix ( $\mathrm{g} / \mathrm{kg}$ premix): $L$-valine was added to obtain graded level of valine, and the amount of wheat flour and $L$-glycine were reduced to compensate, each mixture was made isonitrogenous. Per kilogram of valine and glycine premix composition from diet 1 to 6 was as follows $(\mathrm{g} / \mathrm{kg}): 0.0,20.3,40.6,60.9,81.2,101.5 \mathrm{~g}$ 
valine, 63.6, 50.9, 38.1, 25.4, 12.7, 0.0 L-glycine and 936.4, 928.8, 921.2, 913.7, 906.1, $898.5 \mathrm{~g}$ wheat flour, respectively.

${ }^{6}$ Crude protein, crude lipid, and ash contents were measured by using the Association of Official Analytical Chemists Methods. Valine content was measured using high-performance liquid chromatography (Agilent Technologies, Palo Alto, CA, USA).

Table 2 Primer sequences and optimal annealing temperatures $\left(\mathrm{OAT},{ }^{\circ} \mathrm{C}\right)$ of genes selected for analysis by realtime PCR 


\begin{tabular}{|c|c|c|c|}
\hline Name & Sequences & OAT & Accession number \\
\hline SOD1-QF & САТTTСААТССССАСАACAAGA & 63.3 & FJ030929.1 \\
\hline SOD1-QR & СTTTGCGACATTATCTGCTCCT & & \\
\hline CAT-QF & ATGCCGCTGGCGAATGT & 63.3 & MK614708.1 \\
\hline CAT-QR & GCATAATCTGGGTTGGTGGAA & & \\
\hline GST-QF & AATGGAGCACAAGTCACAGGA & 63.3 & AY335905.1 \\
\hline GST-QR & ACAAGCAGGCAGCATAGGA & & \\
\hline$G P x-Q F$ & GCAATCAGTTTGGACATCAGG & 63.3 & MK614713.1 \\
\hline$G P x-Q R$ & TТССАТТСАСАТССАССТТСТ & & \\
\hline GR-QF & TTATGTCGGTCACCTAAATCG & 62.2 & MW465392 \\
\hline GR-QR & CCTGGAACTTCAGCATCACTC & & \\
\hline GCLC-QF & TACGGTGGCACGATGTCAGA & 62.7 & AY307950.1 \\
\hline$G C L C-\mathrm{QR}$ & GGCAACCTAACCTTGGAAATG & & \\
\hline Nrf2-QF & TCCCCAGAGCAGACAGTTCC & 62.7 & MW465398 \\
\hline Nrf2-QR & СTCCATTTGCATGTTCAGGC & & \\
\hline Keap 1-QF & GATAGACAGCGTGGTCAAGGC & 62.7 & MW465394 \\
\hline Keap 1-QR & TGAAGAACTCCTCCTGGGTCG & & \\
\hline GRP78-QF & AGGGCAGGTACTTGATGTCC & 63.3 & MW465403 \\
\hline GRP78-QR & GGTGAGCGTCTGATTGGTG & & \\
\hline ATF6-QF & CACAGATGGTGAGGTGAGC & 56.8 & MW465385 \\
\hline ATF6-QR & GAGTGGACCGAAACAGGAG & & \\
\hline IRE1-QF & CGAGGTTCTGAGCGAGGAC & 54.7 & MW465393 \\
\hline IRE1-QR & GGCTGTATGTGCCCAGTAGG & & \\
\hline PERK-QF & TTCACTGGACGGTGCCTTG & 57.9 & MW465400 \\
\hline PERK-QR & CCGCAGAGCAGATGTAACGA & & \\
\hline elF2a-QF & AAACCTCAGGCTCCAGACG & 64.5 & MW465408 \\
\hline elF2a-QR & GCCGGTGTAGTGCCAGAT & & \\
\hline ATF4-QF & CGACAGCGACTCAGGCATAG & 56.0 & MW465383 \\
\hline ATF4-QR & GGAGCACCAGACACCGATTT & & \\
\hline CHOP-QF & GAGTTGGAGGCGTGGTATG & 58.2 & XM_038697521.1 \\
\hline CHOP-QR & ATCCGTCAGCCAGGTCAG & & \\
\hline$B c / 2-Q F$ & $\begin{array}{c}\text { GGCTGGAGATGAACTTGAAAGACTA } \\
\text { Page } 18 / 28\end{array}$ & 62.5 & MW465389 \\
\hline
\end{tabular}




\begin{tabular}{|llll|}
\hline Bcl2-QR & CCGAACTCGAAGAAAGCGATAAT & & \\
\hline Bax-QF & CCAGCAGATTGGAGATGAGCC & 55.0 & MW465388 \\
\hline Bax-QR & CGACAGGCAAAGTAGAACAGT & & \\
\hline caspase 9-QF & CTGGAATGCCTTCAGGAGACGGG & 59.0 & Sun et al., 2020 \\
\hline caspase 9-QR & GGGAGGGGCAAGACAACAGGGTG & & \\
caspase 3-QF & GCTTCATTCGTCTGTGTTC & 61.5 & RNA-seq by Ref. \\
\hline caspase 3-QR & CGAAAAAGTGATGTGAGGTA & & \\
\hline$\beta$-actin-QF & CCCCATCCACCATGAAGA & 55.7 & KJ669297.1 \\
\hline$\beta$-actin-QR & CCTGCTTGCTGATCCACAT & & \\
\hline 18S-QF & TGAATACCGCAGCTAGGAATAATG & 59.0 & MH018569.1 \\
\hline 18S-QR & CCTCCGACTTTCGTTCTTGATT & & \\
\hline
\end{tabular}

Table 3 The growth performance and feed utilization of largemouth bass fed diets with graded levels of Val ( $\mathrm{g} / \mathrm{kg}$ diet) for $77 d^{1}$. 


\begin{tabular}{|c|c|c|c|c|c|c|}
\hline \multirow[t]{2}{*}{ Items } & \multicolumn{6}{|c|}{ Dietary Val levels } \\
\hline & 11.0 & 14.0 & 17.0 & 20.1 & 23.1 & 26.2 \\
\hline $\mathrm{SR}^{2}$ & $98.33 \pm 0.83$ & $99.17 \pm 0.83$ & $100.00 \pm 0.00$ & $99.17 \pm 0.83$ & $99.17 \pm 0.83$ & $100.00 \pm 0.00$ \\
\hline FBW & $152.9 \pm 0.6^{a}$ & $159.5 \pm 0.4^{b}$ & $161.6 \pm 0.5^{\mathrm{b}}$ & $168.8 \pm 1.3^{d}$ & $169.3 \pm 0.3^{d}$ & $165.3 \pm 1.2^{c}$ \\
\hline $\mathrm{PWG}^{3}$ & $302.4 \pm 1.6^{a}$ & $319.8 \pm 1.1^{b}$ & $325.1 \pm 1.3^{b}$ & $344.2 \pm 3.5^{d}$ & $345.6 \pm 0.8^{d}$ & $335.1 \pm 3.2^{c}$ \\
\hline $\mathrm{SGR}^{4}$ & $1.81 \pm 0.01^{\mathrm{a}}$ & $1.86 \pm 0.00^{b}$ & $1.88 \pm 0.00^{b}$ & $1.94 \pm 0.01^{d}$ & $1.94 \pm 0.00^{d}$ & $1.91 \pm 0.01^{\mathrm{c}}$ \\
\hline $\mathrm{FI}$ & $126.2 \pm 0.6^{a}$ & $126.4 \pm 0.5^{\mathrm{a}}$ & $131.0 \pm 0.4^{\mathrm{b}}$ & $133.8 \pm 1.8^{c}$ & $133.9 \pm 0.3^{c}$ & $131.1 \pm 0.2^{b}$ \\
\hline $\mathrm{FE}^{5}$ & $89.58 \pm 0.86^{a}$ & $93.68 \pm 0.43^{b}$ & $94.33 \pm 0.61^{b}$ & $97.77 \pm 1.15^{\mathrm{cd}}$ & $98.10 \pm 0.02^{d}$ & $94.63 \pm 1.92^{\mathrm{bc}}$ \\
\hline $\mathrm{PER}^{6}$ & $198.3 \pm 1.7^{a}$ & $209.6 \pm 0.2^{b c}$ & $205.4 \pm 1.4^{\mathrm{b}}$ & $212.9 \pm 2.6^{c}$ & $213.7 \pm 0.0^{c}$ & $211.7 \pm 2.0^{c}$ \\
\hline $\mathrm{PPV}^{7}$ & $31.13 \pm 0.18^{a}$ & $33.82 \pm 0.15^{\mathrm{b}}$ & $33.75 \pm 0.38^{b}$ & $34.94 \pm 0.39^{c}$ & $34.51 \pm 0.22^{b c}$ & $33.92 \pm 0.29^{b}$ \\
\hline LPV $^{8}$ & $71.76 \pm 0.7^{a}$ & $74.49 \pm 0.59^{b}$ & $77.08 \pm 0.46^{\mathrm{bc}}$ & $79.02 \pm 1.41^{\mathrm{c}}$ & $76.93 \pm 0.18^{b c}$ & $76.26 \pm 0.96^{b}$ \\
\hline APV ${ }^{9}$ & $31.85 \pm 0.44^{\mathrm{a}}$ & $33.81 \pm 0.38^{\mathrm{ab}}$ & $33.85 \pm 0.86^{\mathrm{ab}}$ & $35.43 \pm 0.41^{\mathrm{b}}$ & $35.51 \pm 0.19^{b}$ & $33.84 \pm 1.23^{\mathrm{ab}}$ \\
\hline \multicolumn{4}{|c|}{ Regression } & $x$ & $\mathrm{R}^{2}$ & $P$ \\
\hline \multicolumn{4}{|c|}{$Y_{F B W}=-0.116 X^{2}+5.249 X+108.656$} & 22.63 & 0.931 & $<0.05$ \\
\hline \multicolumn{4}{|c|}{$Y_{P W G}=-0.304 X^{2}+13.731 X+186.605$} & 22.58 & 0.930 & $<0.05$ \\
\hline \multicolumn{4}{|c|}{$Y_{S G R}=-0.001 X^{2}+0.043 X+1.451$} & 21.50 & 0.931 & $<0.05$ \\
\hline \multicolumn{4}{|c|}{$Y_{F I}=-0.065 X^{2}+2.875 X+101.086$} & 22.12 & 0.834 & 0.068 \\
\hline \multicolumn{4}{|c|}{$Y_{F E}=-0.076 X^{2}+3.233 X+63.038$} & 21.27 & 0.900 & $<0.05$ \\
\hline \multicolumn{4}{|c|}{$Y_{P P V}=-0.035 X^{2}+1.448 X+19.651$} & 20.69 & 0.904 & $<0.05$ \\
\hline \multicolumn{4}{|c|}{$Y_{L P V}=-0.069 X^{2}+2.879 X+48.267$} & 20.68 & 0.942 & $<0.05$ \\
\hline \multicolumn{4}{|c|}{$Y_{A P V}=-0.035 X^{2}+1.457 X+20.000$} & 20.83 & 0.869 & $<0.05$ \\
\hline
\end{tabular}

${ }^{1}$ SR, survival rate (\%); FBW, final body weight (g/fish); PWG, percent weight gain (\%); SGR, specific growth rate $(\% / \mathrm{d}) ; \mathrm{Fl}$, feed intake (g/fish); FE, feed efficiency (\%); PER, protein efficiency ratio (\%); PPV, protein production value (\%); LPV, lipid production value (\%); APV, ash production value (\%). Values are mean \pm S.E. of three replicate groups with nine fish in each group, while quadratic regression was run with the triplicate data points. Values within the same rows having different superscripts are significantly different $(P<0.05)$.

${ }^{2} \mathrm{SR}=100 \times$ (final number of fish / initial number of fish)

${ }^{3} \mathrm{PWG}=100 \times$ weight gain $(\mathrm{g}) /$ initial weight $(\mathrm{g})$ 
${ }^{4} \mathrm{SGR}=100 \times[$ In (mean final weight) - In (mean initial weight) $] / 77$ days

${ }^{5} \mathrm{FE}=100 \times$ weight gain $(\mathrm{g}) /$ feed intake $(\mathrm{g})$

${ }^{6}$ PER $=100 \times$ weight gain $(g) /$ protein intake $(g)$

${ }^{7}$ PPV $=100 \times$ fish protein gain $(g) /$ total protein intake $(g)$.

${ }^{8}$ LPV $=100 \times$ fish lipid gain $(g) /$ total lipid intake $(g)$.

${ }^{9} \mathrm{APV}=100 \times$ fish ash gain $(\mathrm{g}) /$ total ash intake $(\mathrm{g})$

Table 4 Intestinal histopathological score in largemouth bass fed with graded levels of Val (g/kg diet) for $77 \mathrm{~d}$ after infection with $A$. veronii ${ }^{1}$.

\begin{tabular}{|c|c|c|c|c|c|c|}
\hline \multirow[t]{2}{*}{ Items } & \multicolumn{6}{|c|}{ Dietary Val levels } \\
\hline & 11.0 & 14.0 & 17.0 & 20.1 & 23.1 & 26.2 \\
\hline Inflammation ${ }^{2}$ & $2.50 \pm 0.19^{b c}$ & $2.75 \pm 0.16^{c}$ & $2.25 \pm 0.16^{b c}$ & $1.25 \pm 0.16^{a}$ & $1.38 \pm 0.26^{a}$ & $2.13 \pm 0.23^{b}$ \\
\hline Extent $^{3}$ & $2.38 \pm 0.18^{c}$ & $2.13 \pm 0.13^{b c}$ & $1.88 \pm 0.13^{b}$ & $1.25 \pm 0.16^{a}$ & $1.00 \pm 0.00^{a}$ & $1.88 \pm 0.23^{b}$ \\
\hline $\begin{array}{l}\text { Percent } \\
\text { involvement }^{4}\end{array}$ & $3.13 \pm 0.30^{c}$ & $2.88 \pm 0.23^{b c}$ & $2.25 \pm 0.16^{b}$ & $0.88 \pm 0.23^{a}$ & $0.88 \pm 0.30^{a}$ & $2.38 \pm 0.18^{b}$ \\
\hline $\begin{array}{l}\text { Histopathological } \\
\text { score }^{5}\end{array}$ & $8.00 \pm 0.50^{c}$ & $7.75 \pm 0.25^{c}$ & $6.38 \pm 0.26^{b}$ & $3.38 \pm 0.32^{a}$ & $3.25 \pm 0.49^{a}$ & $6.38 \pm 0.42^{b}$ \\
\hline
\end{tabular}

${ }^{1}$ Values are mean \pm S.E. of three fish from each group, the same rows having different superscripts are significantly different $(P<0.05)$.

${ }^{2}$ Inflammation is expressed on a 0-3 score: none (0); slight (1); moderate (2); severe (3).

${ }^{3}$ Extent is expressed on a $0-3$ score: none (0); mucosa (1); mucosa and submucosa (2); transmural (3).

${ }^{4}$ Percent involvement is expressed on a $0-4$ score: none (0); $1-25 \%$ (1); $26-50 \%$ (2); $51-75 \%$ (3); 76-100\% (4).

${ }^{5}$ Histopathology score $=$ inflammation score + extent score + percent involvement score.

Table 5 The contents of ROS, MDA, PC, GSH, and activities of ASA, AHR, SOD, CAT, GST, GPx, and GR in intestine of largemouth bass fed diet with graded levels of $\mathrm{Val}\left(\mathrm{g} / \mathrm{kg}\right.$ diet) for $77 \mathrm{~d}$ after infection with $A$. veronii ${ }^{1}$. 


\begin{tabular}{|c|c|c|c|c|c|c|}
\hline \multirow[t]{2}{*}{ Items } & \multicolumn{6}{|c|}{ Dietary Val levels } \\
\hline & 11.0 & 14.0 & 17.0 & 20.1 & 23.1 & 26.2 \\
\hline ROS & $100.00 \pm 1.19^{d}$ & $80.28 \pm 1.51^{c}$ & $76.21 \pm 2.48^{b c}$ & $68.46 \pm 0.70^{a}$ & $72.22 \pm 1.35^{a b}$ & $74.68 \pm 1.37^{b}$ \\
\hline MDA & $0.90 \pm 0.03^{c}$ & $0.75 \pm 0.02^{b}$ & $0.74 \pm 0.03^{b}$ & $0.63 \pm 0.04^{a}$ & $0.71 \pm 0.02^{a b}$ & $0.72 \pm 0.04^{b}$ \\
\hline PC & $10.26 \pm 0.21^{d}$ & $8.38 \pm 0.63^{c}$ & $6.77 \pm 0.33^{b}$ & $5.26 \pm 0.22^{a}$ & $5.55 \pm 0.37^{a}$ & $7.10 \pm 0.47^{b}$ \\
\hline ASA & $358.9 \pm 9.7^{a}$ & $382.6 \pm 10.7^{a b}$ & $405.4 \pm 5.3^{b c}$ & $412.5 \pm 10.8^{c}$ & $399.5 \pm 7.5^{b c}$ & $389.9 \pm 3.5^{b c}$ \\
\hline AHR & $256.1 \pm 10.4^{a}$ & $306.7 \pm 11.4^{b c}$ & $348.6 \pm 0.8^{d}$ & $371.7 \pm 10.0^{d}$ & $311.5 \pm 2.7^{c}$ & $285.8 \pm 6.8^{b}$ \\
\hline T-SOD & $64.06 \pm 1.63^{a}$ & $74.74 \pm 2.33^{b c}$ & $83.85 \pm 2.87^{c}$ & $88.63 \pm 1.79^{c}$ & $84.38 \pm 2.70^{c}$ & $74.57 \pm 3.63^{b}$ \\
\hline CAT & $5.53 \pm 0.25^{a}$ & $7.24 \pm 0.11^{c}$ & $7.37 \pm 0.06^{c}$ & $8.41 \pm 0.04^{d}$ & $8.26 \pm 0.15^{d}$ & $6.18 \pm 0.18^{b}$ \\
\hline GST & $169.7 \pm 2.2^{a}$ & $188.0 \pm 4.0^{b}$ & $215.9 \pm 7.8^{c}$ & $242.7 \pm 3.3^{d}$ & $194.1 \pm 4.3^{b}$ & $182.8 \pm 3.5^{a b}$ \\
\hline GPx & $140.4 \pm 14.1^{a}$ & $164.2 \pm 1.0^{\mathrm{bc}}$ & $175.6 \pm 1.9^{b c d}$ & $186.9 \pm 2.9^{d}$ & $182.5 \pm 3.8^{\mathrm{cd}}$ & $158.5 \pm 2.3^{b}$ \\
\hline GR & $10.94 \pm 0.33^{a}$ & $13.7 \pm 0.58^{a b}$ & $19.65 \pm 1.36^{c d}$ & $21.96 \pm 2.45^{d}$ & $17.27 \pm 1.33^{b c}$ & $12.97 \pm 0.61^{a}$ \\
\hline GSH & $9.25 \pm 0.64^{a}$ & $13.09 \pm 0.21^{b}$ & $14.91 \pm 0.16^{c}$ & $15.31 \pm 0.22^{c}$ & $12.05 \pm 0.44^{b}$ & $8.07 \pm 0.59^{a}$ \\
\hline \multicolumn{3}{|c|}{ Regression } & \multicolumn{2}{|l|}{$x$} & $\mathrm{R}^{2}$ & $P$ \\
\hline \multicolumn{3}{|c|}{$Y_{\text {ROS }}=0.276 X^{2}-11.748 X+194.202$} & \multicolumn{2}{|l|}{21.28} & 0.958 & $<0.05$ \\
\hline \multicolumn{3}{|c|}{$Y_{M D A}=0.002 X^{2}-0.094 X+1.656$} & \multicolumn{2}{|l|}{23.50} & 0.876 & $<0.05$ \\
\hline \multicolumn{3}{|c|}{$Y_{P C}=0.048 X^{2}-2.035 X+27.083$} & \multicolumn{2}{|l|}{21.20} & 0.966 & $<0.05$ \\
\hline \multicolumn{3}{|c|}{$Y_{A S A}=-0.600 X^{2}+24.289 X+163.331$} & \multicolumn{2}{|l|}{20.24} & 0.970 & $<0.05$ \\
\hline \multicolumn{3}{|c|}{$Y_{A H R}=-1.527 X^{2}+58.529 X-205.579$} & \multicolumn{2}{|l|}{19.16} & 0.905 & $<0.05$ \\
\hline \multicolumn{3}{|c|}{$Y_{S O D}=-0.303 X^{2}+12.062 X-33.079$} & \multicolumn{2}{|l|}{19.90} & 0.982 & $<0.05$ \\
\hline \multicolumn{3}{|c|}{$Y_{\text {CAT }}=-0.039 X^{2}+1.519 X-6.544$} & \multicolumn{2}{|l|}{19.47} & 0.870 & $<0.05$ \\
\hline \multicolumn{3}{|c|}{$Y_{G P x}=-0.588 X^{2}+23.316 X-46.442$} & \multicolumn{2}{|l|}{19.83} & 0.967 & $<0.05$ \\
\hline \multicolumn{3}{|c|}{$Y_{G R}=-0.151 X^{2}+5.830 X-36.049$} & \multicolumn{2}{|l|}{19.30} & 0.884 & $<0.05$ \\
\hline \multicolumn{3}{|c|}{$Y_{G S H}=-0.115 X^{2}+4.187 X-22.951$} & \multicolumn{2}{|l|}{18.20} & 0.989 & $<0.05$ \\
\hline
\end{tabular}

${ }^{1}$ ROS, reactive oxygen species (\%); MDA, malondialdehyde (nmol/mg protein); PC, protein carbonyl (nmol/mg protein); GSH, glutathione (mmol/g tissue); ASA, anti-superoxide anion (U/mg protein); AHR, anti-hydroxyl radical (U/mg protein); SOD, superoxide dismutase (U/mg protein); CAT, catalase (U/mg protein); GST, glutathione- 
S-transferase (U/mg protein); GPx, glutathione peroxidase (U/mg protein); GR, glutathione reductase (U/mg protein). Values are mean \pm S.E. of three replicates groups with three fish in each group, while quadratic regression was run with the triplicate data points. Values within the same rows having different superscripts are significantly different $(P<0.05)$.

Table 6 Correlation analysis of parameters in the intestine of largemouth bass

\begin{tabular}{|c|c|c|c|c|}
\hline Items & Independent parameters & Dependent parameters & Correlation coefficients & $P$ \\
\hline \multirow[t]{6}{*}{ Feeding trial } & SGR & $\mathrm{FI}$ & 0.937 & 0.006 \\
\hline & & $\mathrm{FE}$ & 0.973 & 0.001 \\
\hline & FE & PER & 0.914 & 0.011 \\
\hline & & PPV & 0.945 & 0.004 \\
\hline & & LPV & 0.904 & 0.013 \\
\hline & & APV & 0.996 & 0.000 \\
\hline \multirow[t]{19}{*}{ challenge test } & ROS & MDA & 0.976 & 0.001 \\
\hline & & PC & 0.949 & 0.004 \\
\hline & & ASA & -0.935 & 0.006 \\
\hline & & AHR & -0.767 & 0.075 \\
\hline & & SOD & -0.901 & 0.014 \\
\hline & & CAT & -0.805 & 0.053 \\
\hline & & GPx & -0.892 & 0.017 \\
\hline & & GRP78 mRNA & 0.794 & 0.059 \\
\hline & & ATF6 mRNA & 0.883 & 0.020 \\
\hline & & CHOP mRNA & 0.864 & 0.026 \\
\hline & & caspase $3 \mathrm{mRNA}$ & 0.853 & 0.031 \\
\hline & SOD1 mRNA & SOD & 0.861 & 0.028 \\
\hline & CAT mRNA & CAT & 0.966 & 0.002 \\
\hline & GPx mRNA & GPx & 0.840 & 0.036 \\
\hline & Nrf2 mRNA & CAT mRNA & 0.962 & 0.002 \\
\hline & & $G R$ mRNA & 0.810 & 0.051 \\
\hline & & GCLC mRNA & 0.925 & 0.008 \\
\hline & Bcl2 mRNA & caspase $9 \mathrm{mRNA}$ & -0.800 & 0.056 \\
\hline & & caspase $3 \mathrm{mRNA}$ & -0.840 & 0.036 \\
\hline
\end{tabular}




\section{Figures}

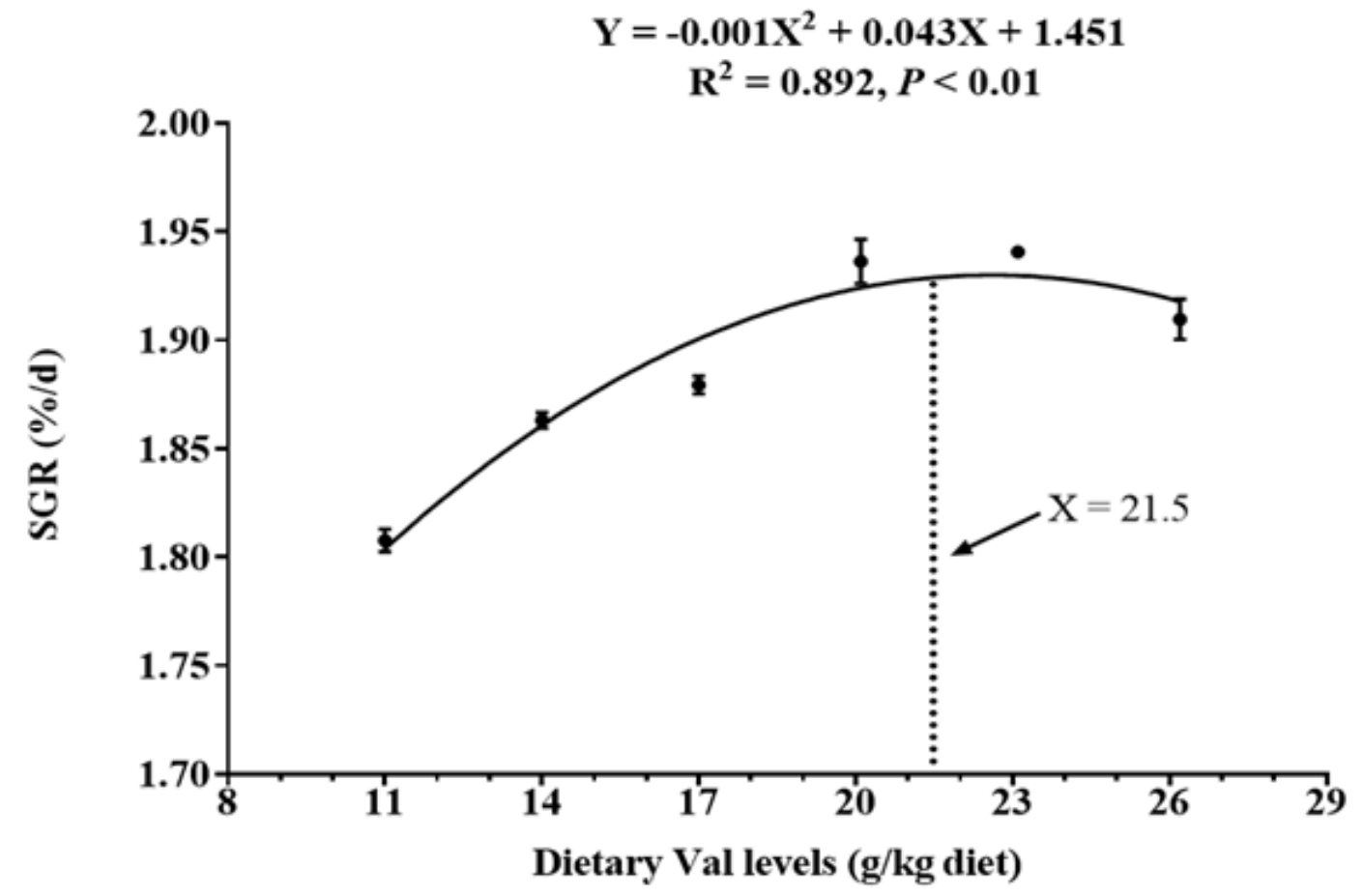

Figure 1

Quadratic regression analysis of specific growth rate (SGR) for largemouth bass fed diets with graded levels of Val for 77 days.

Dietary Val levels ( $\mathrm{g} / \mathrm{kg}$ diet)

- $11.0 \quad$ † $14.0 \quad$ - $17.0 \quad$ - $20.1 \quad$ - $23.1 \quad$ * 26.2

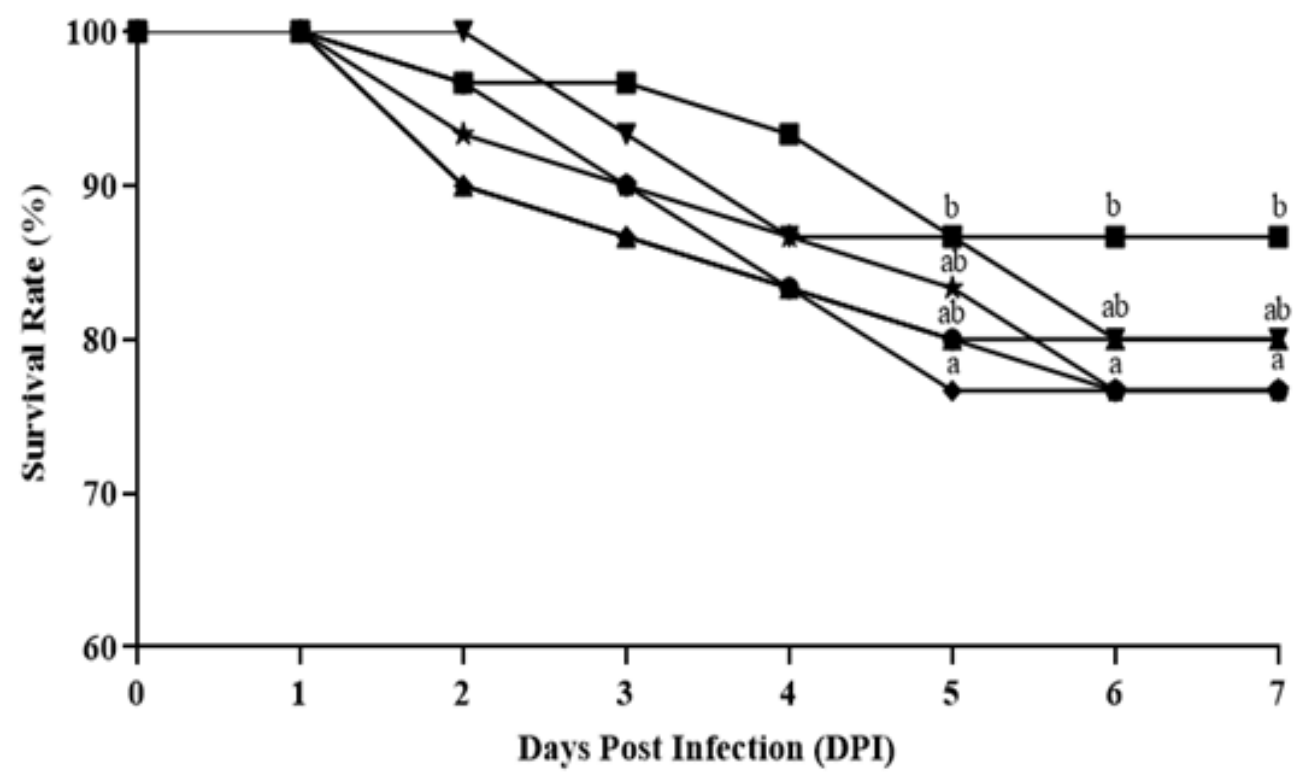


Figure 2

The survival rate of largemouth bass fed diets with graded levels of Val for 77 days after infection with A. veronii.
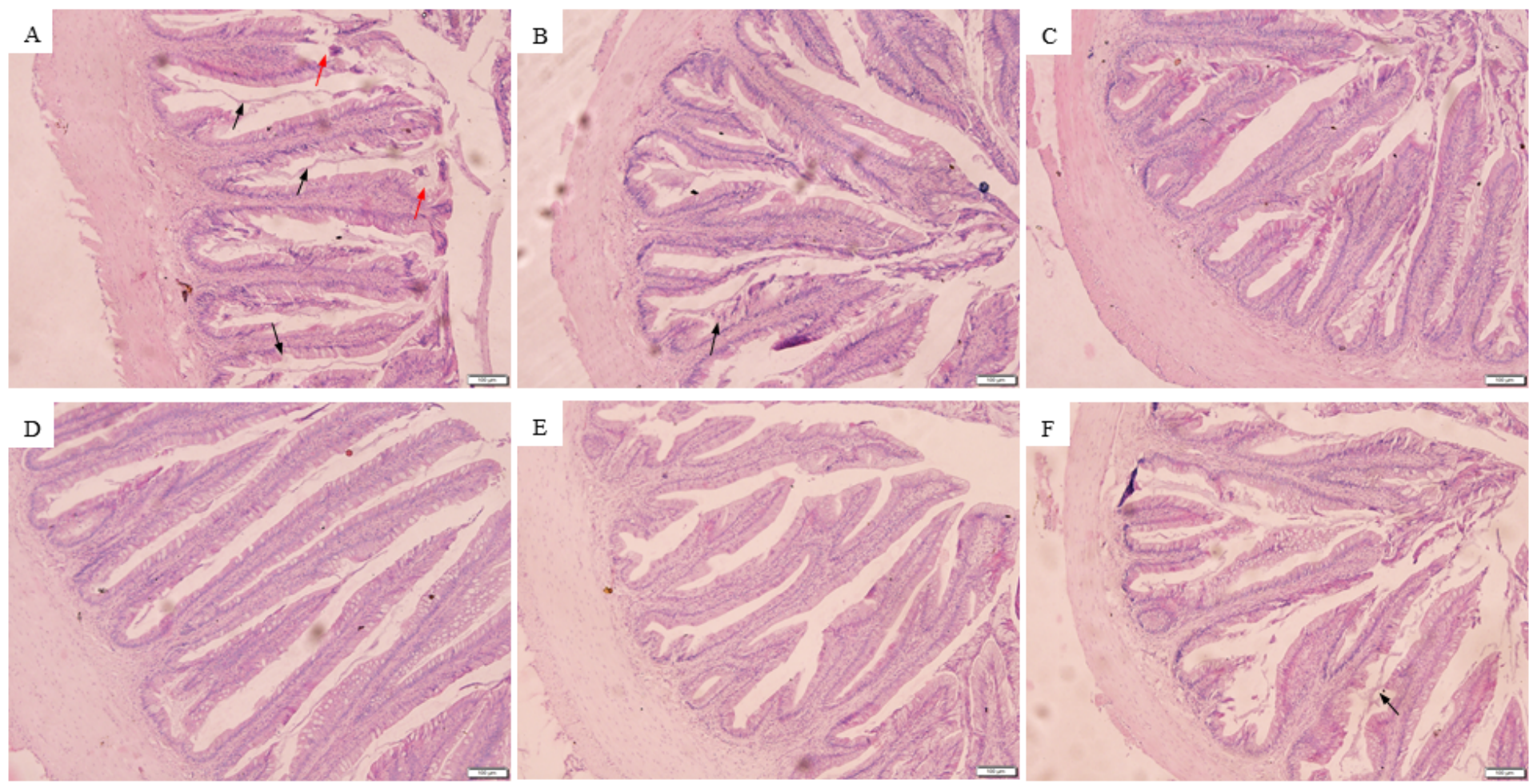

Figure 3

The intestinal (A-F) histological morphology of largemouth bass fed diets with graded levels of Val for 77 days after infection with $A$. veronii. $A, B, C, D, E$, and $F$ represent the 11.0, 14.0, 17.0, 20.1, 23.1 and $26.2 \mathrm{~g} \mathrm{Val} \mathrm{kg-1} \mathrm{diet,}$ respectively (H\&E × 100, scale $100 \mu \mathrm{m})$.

Dietary Val levels (g/kg diet)

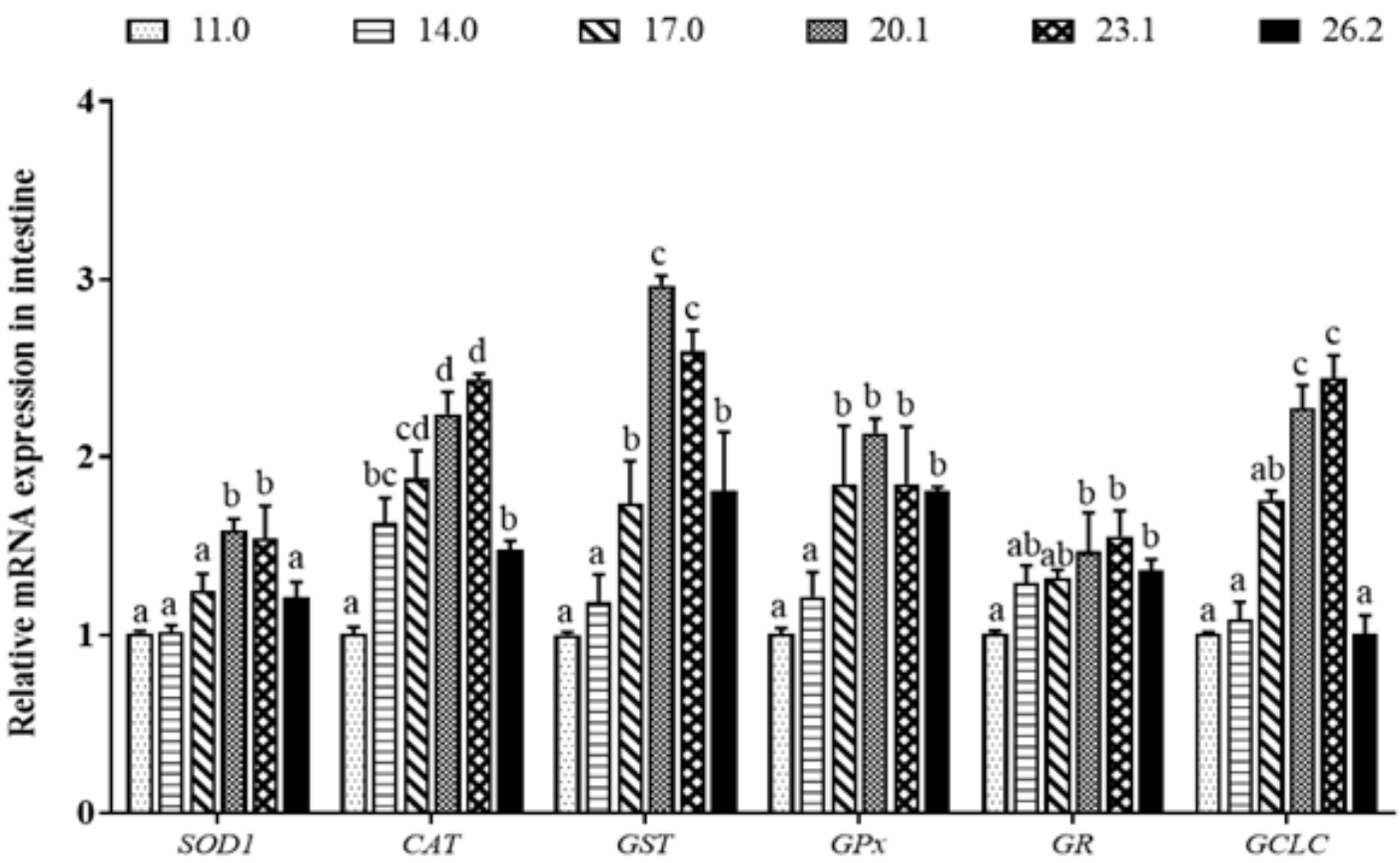


Figure 4

Relative mRNA expressions of SOD1, CAT, GST, GPX, GR, and GCLC in intestine. Values are means \pm S.E., of three replicates groups with six fish in each group, and different letter denotes significant difference $(P<0.05)$.

Dietary Val levels (g/kg diet)

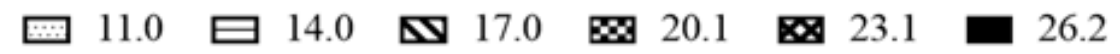

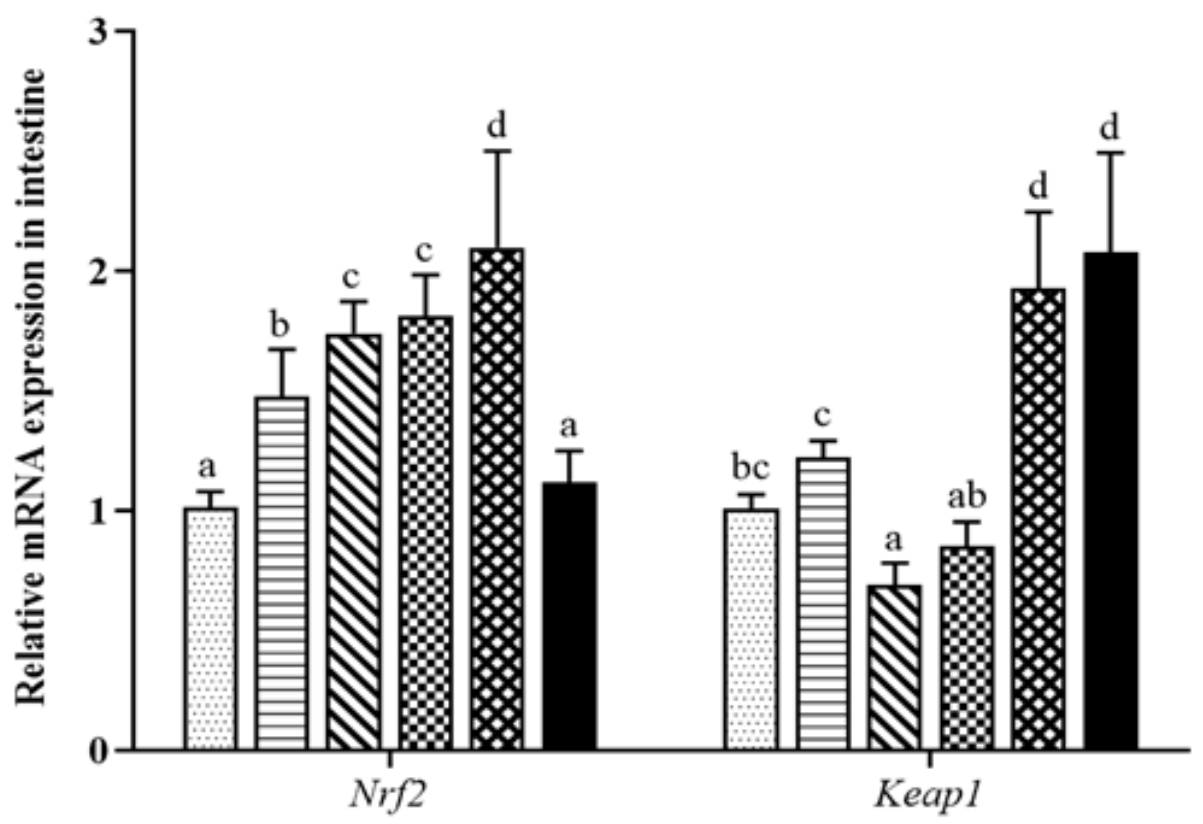

Figure 5

Relative mRNA expressions of Nrf2 and Keap1 in intestine. Values are means \pm S.E., of three replicates groups with six fish in each group, and different letter denotes significant difference $(P<0.05)$.
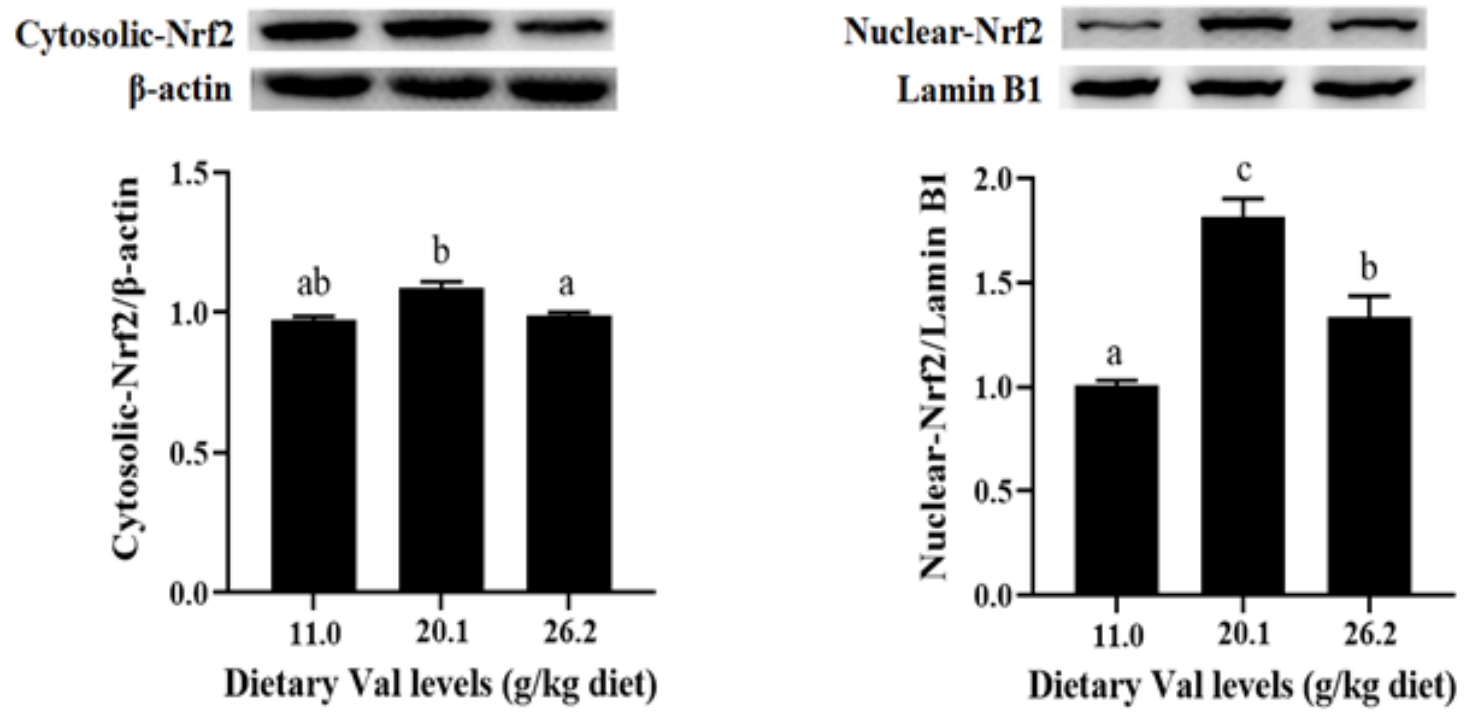

Figure 6 
Effects of dietary Val on Keap1 and Nrf2 protein expressions in intestine. The cytosolic-Keap1, cytosolic-Nrf2 (equal loading was monitored with anti- $\beta$-actin antibody), nuclear-Nrf2 (equal loading was monitored with lamin B1 antibody) protein levels were determined by western blot analysis. Values are means \pm S.E., of three replicates with six fish in each group, and different letter denotes significant difference $(P<0.05)$.

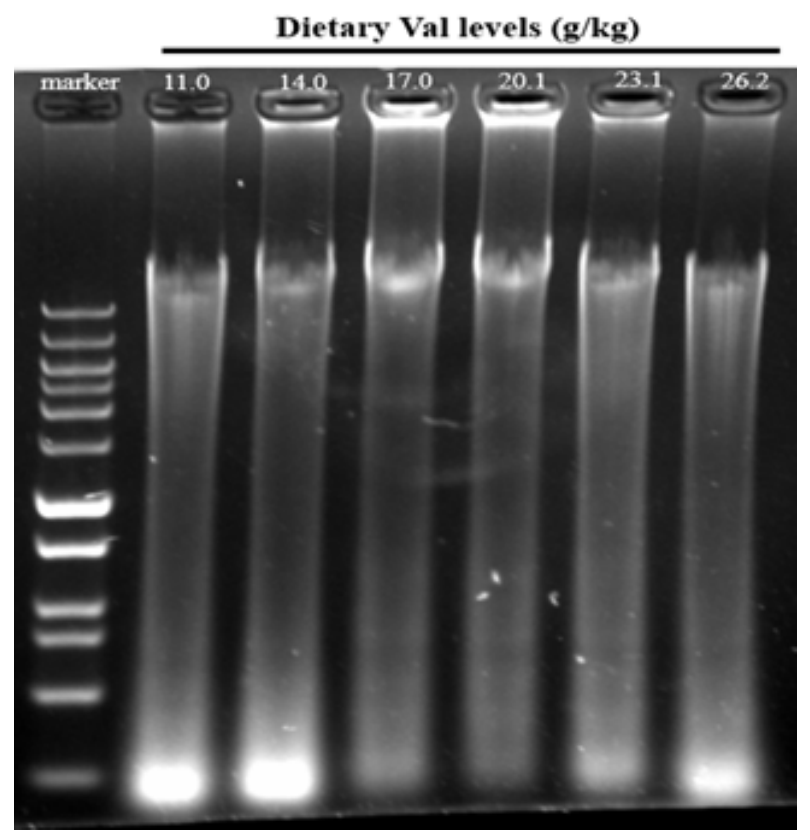

Figure 7

The DNA fragmentation in intestine of largemouth bass fed diets with graded levels of Val for 77 days after infection with $\mathrm{A}$. veronii.

Dietary Val levels (g/kg diet)

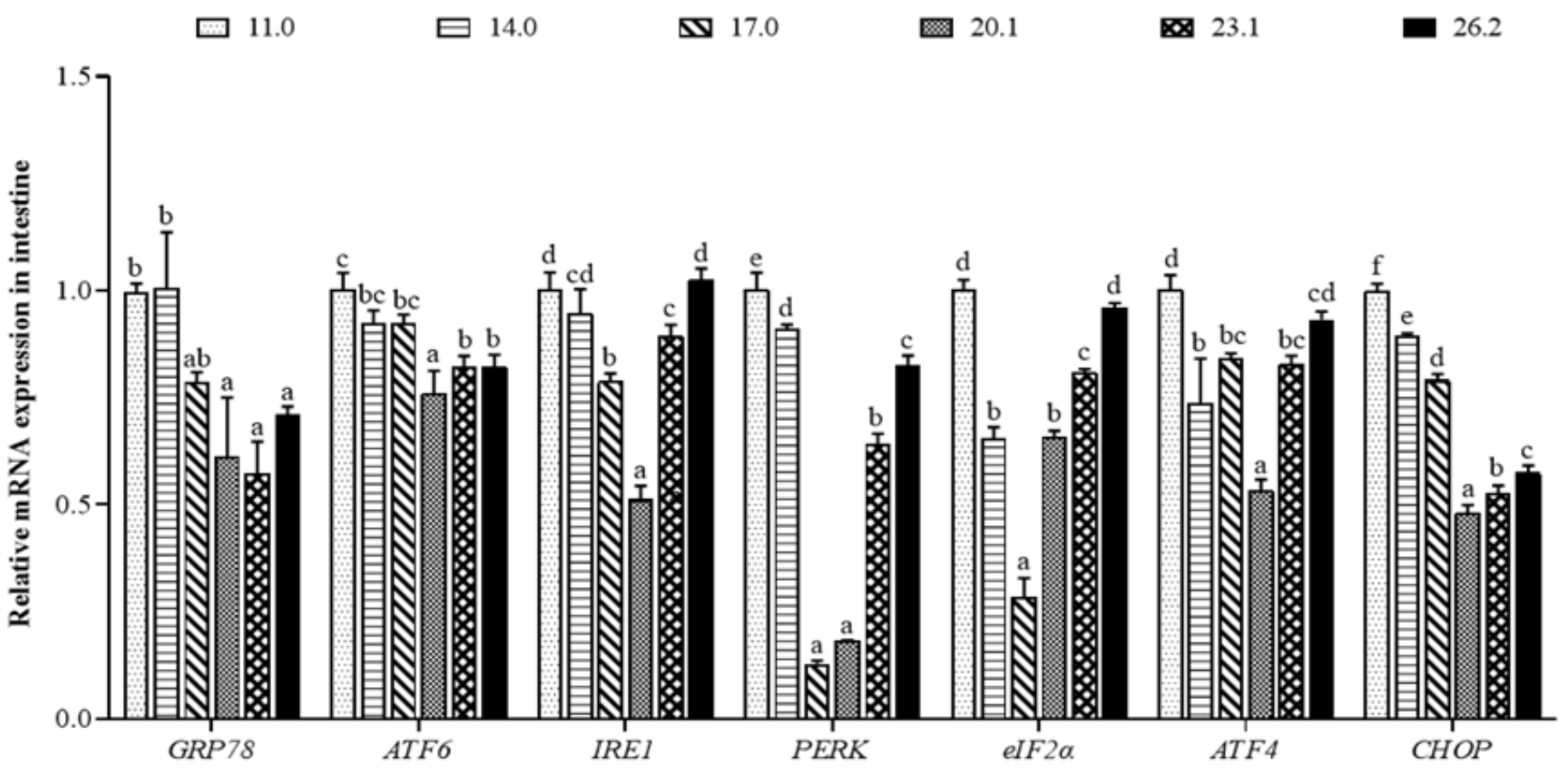

Figure 8 
Relative mRNA expressions of GRP78, ATF6, IRE1, PERK, elF2a, ATF4, and CHOP in intestine. Values are means \pm S.E., of three replicates groups with six fish in each group, and different letter denotes significant difference $(P<$ 0.05).

\section{Dietary Val levels (g/kg diet)}

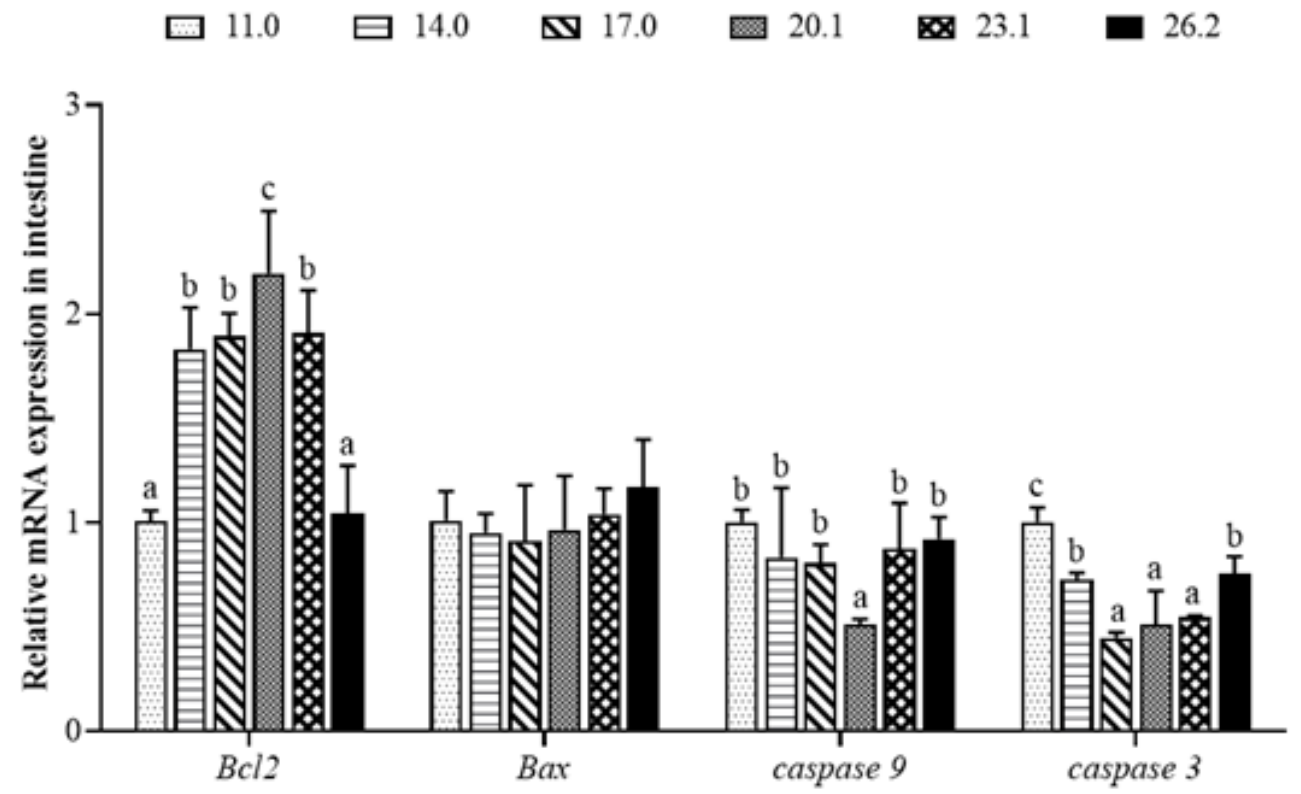

Figure 9

Relative mRNA expressions of $\mathrm{Bax}, \mathrm{Bcl} 2$, caspase 9 and caspase 3 in intestine. Values are means \pm S.E., of three replicates groups with six fish in each group, and different letter denotes significant difference $(P<0.05)$.
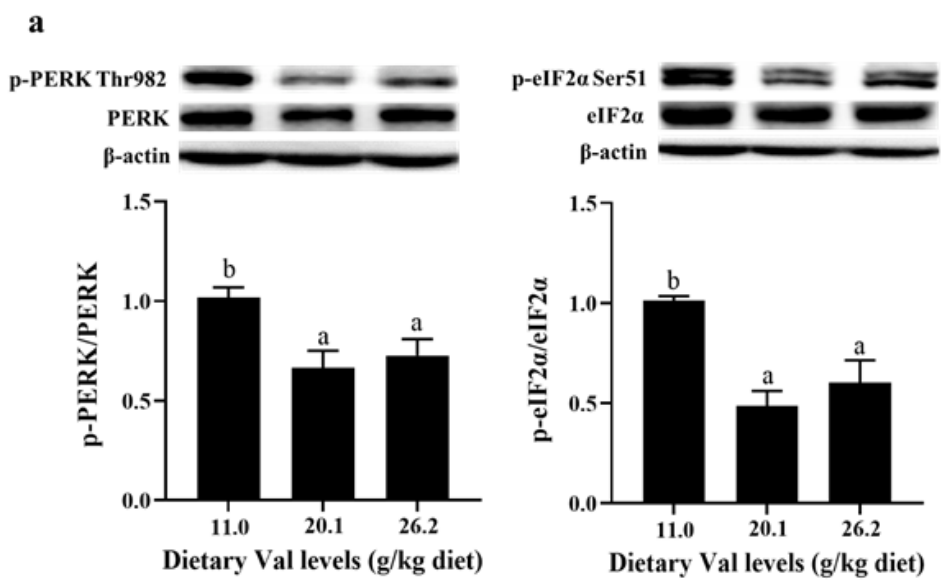

b
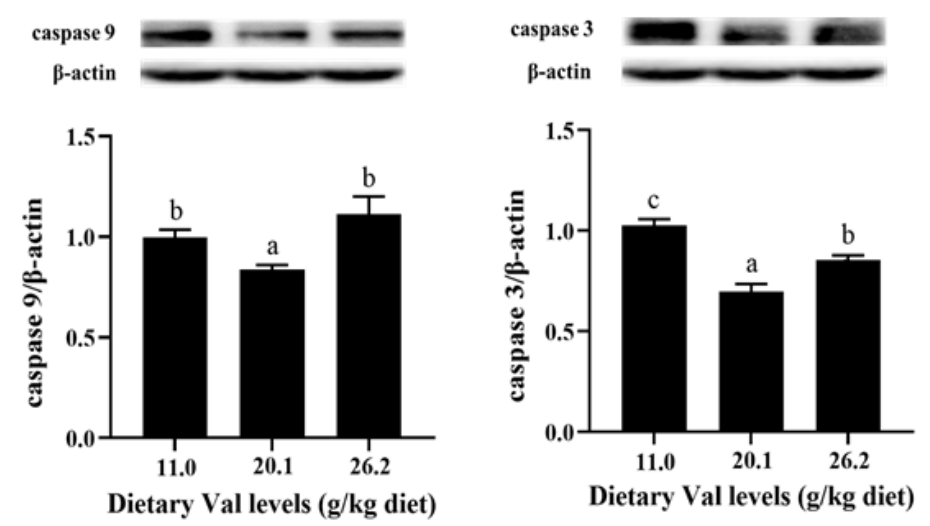

Figure 10

Effects of dietary Val on PERK/elF2a signaling pathway in intestine after infection with A. veronii. The PERK, pPERK, elF2a, p-elF2a, caspase 3, and caspase 9 protein levels were determined by western blot analysis. Equal loading was monitored with anti- $\beta$-actin antibody. Values are means $\pm S E M$, of three replicates with six fish in each group, and different letter denotes significant difference $(P<0.05)$. 